\title{
Adenosine and adenosine receptor-mediated action in coronary microcirculation
}

\author{
Ying Zhang ${ }^{1} \cdot$ Bernhard Wernly $^{2} \cdot$ Xin Cao $^{1} \cdot$ S. Jamal Mustafa ${ }^{3} \cdot$ Yong Tang $^{1,4} \cdot$ Zhichao Zhou $^{5}$ (D)
}

Received: 17 August 2020 / Accepted: 8 March 2021 / Published online: 23 March 2021

(c) The Author(s) 2021

\begin{abstract}
Adenosine is an ubiquitous extracellular signaling molecule and plays a fundamental role in the regulation of coronary microcirculation through activation of adenosine receptors (ARs). Adenosine is regulated by various enzymes and nucleoside transporters for its balance between intra- and extracellular compartments. Adenosine-mediated coronary microvascular tone and reactive hyperemia are through receptors mainly involving $\mathrm{A}_{2 \mathrm{~A}} \mathrm{R}$ activation on both endothelial and smooth muscle cells, but also involving interaction among other ARs. Activation of ARs further stimulates downstream targets of $\mathrm{H}_{2} \mathrm{O}_{2}, \mathrm{~K}_{\mathrm{ATP}}, \mathrm{K}_{\mathrm{V}}$ and $\mathrm{K}_{\mathrm{Ca} 2+}$ channels leading to coronary vasodilation. An altered adenosine-ARs signaling in coronary microcirculation has been observed in several cardiovascular diseases including hypertension, diabetes, atherosclerosis and ischemic heart disease. Adenosine as a metabolite and its receptors have been studied for its both therapeutic and diagnostic abilities. The present review summarizes important aspects of adenosine metabolism and AR-mediated actions in the coronary microcirculation.
\end{abstract}

Keywords Extracellular nucleotides $\cdot$ Purinergic receptor $\cdot$ Coronary microcirculation $\cdot$ Adenosine $\cdot$ Ischemic heart disease $\cdot$ Diabetes

\section{Introduction}

The coronary microcirculation supplies oxygen and nutrients by determining blood flow to the myocardium through the regulation of vascular resistance. The regulation of coronary microcirculation is essential but complex and is accomplished by changes in coronary microvascular tone, i.e. in contraction and relaxation of vascular smooth muscle,

Zhichao Zhou

zhichao.zhou@ki.se; zhzhou2015@gmail.com

1 The International Collaborative Centre On Big Science Plan for Purinergic Signalling, Chengdu University of Traditional Chinese Medicine, Chengdu, China

2 Department of Anaesthesiology, Perioperative Medicine and Intensive Care Medicine, Paracelsus Medical University of Salzburg, Salzburg, Austria

3 Department of Physiology and Pharmacology, West Virginia University, Morgantown, USA

4 Acupuncture and Chronobiology Key Laboratory of Sichuan Province, Chengdu, China

5 Division of Cardiology, Department of Medicine, Karolinska Institutet, Karolinska University Hospital, 17176 Stockholm, Sweden through integration of factors and multiple signals from the perivascular nerves, the myocardium, the endothelium as well as circulating cells $[47,88]$. Coronary microvascular dysfunction, resulting in impaired oxygenation and lowgrade inflammation, likely contributes to the pathogenesis of coronary microvascular angina [70, 94]. These patients with signs and symptoms of ischemia and non-obstructive coronary artery disease are associated with elevated risk for adverse outcomes [70,94]. However, the diagnosis of coronary microvascular dysfunction is limited, the disease mechanisms are not fully understood and the patients with non-obstructive coronary artery disease remain undertreated $[6,80]$.

Adenosine plays a crucial role in the regulation of coronary microvascular tone and coronary blood flow in both physiology and coronary vascular diseases $[31,36$, 47]. Adenosine is an autacoid produced by the action of ecto-5'-nucleotidase on extracellular adenine nucleotides released from the parenchymal tissues including endothelium, myocardium and erythrocytes [60, 71]. Extracellular adenosine exerts its vascular effect via interaction with specific cell-surface receptors located on the smooth muscle and endothelial cells of the coronary vasculature. There are four adenosine receptor (AR) subtypes, namely $A_{1} R, A_{2 A} R$, 
$A_{2 B} R$, and $A_{3} R$. $A_{1} R$ and $A_{3} R$ are negatively coupled to adenylyl cyclase through the Gi/o protein alpha-subunits and activation of those receptors decreases cAMP levels, whereas $A_{2 A} R$ and $A_{2 B} R$ are positively coupled to adenylyl cyclase through Gs and enhance cAMP levels [119]. All four AR subtypes are found in coronary smooth muscle and endothelial cells $[3,31,67,76]$. The distribution of ARs along the branches of coronary arteries also varies. For instance, in the porcine heart, expression of $A_{1} R$ and $A_{2 A} R$ proteins has been documented in the left anterior descending artery, while $A_{1} R, A_{2 A} R$ and $A_{2 B} R$ are expressed in coronary arterioles $[35,108]$. Despite the fact that the $A_{2 B} R$ expression is suggested to be restricted to coronary microvascular origin [27, 63], findings from studies using $A_{2 A} R$ knockout (KO) mice suggested a functional role of $A_{2 B} R$ in regulating larger coronary arteries than previously thought [96]. The primary effect of adenosine in coronary microcirculation is to induce vasodilation and hyperemia [31, 47]. This property of adenosine to modify coronary microvascular function has been used for diagnostic effects for many years and is widely adopted as the gold-standard method of diagnosing ischemia invasively and noninvasively. The therapeutic potential of adenosine and its ARs has also been studied.

This review summarizes important aspects of adenosine and AR-mediated actions in the coronary microcirculation. The main focus is on the evidence addressing the role of adenosine and involvement of ARs in regulation of coronary microvascular function in physiology. We also discuss the pathophysiology of coronary microvascular regulation in several cardiovascular diseases. Finally, this review briefly touches upon the possible therapeutic potential of adenosine and AR modulation. Considering the differences in heart anatomy and metabolism among different species [89], coronary arteries with the diameter below $200 \mu \mathrm{m}$ in human and large animal models are included as microvessels in the present review [85], while the changes in flow measured in vivo and ex vivo are regarded as the vasomotor control of the resistance vessels in human, large animal models and rodents.

\section{Adenosine generation and metabolism}

Adenosine is released in coronary microcirculation from tissues including endothelium, myocardium and erythrocytes at times of cellular stress such as hypoxia, ischemia and inflammation [60]. Adenosine can be formed intracellularly from ATP, ADP or adenosine monophosphate (AMP) by cytoplasmic 5'-nucleosidase activity. The conversion of cAMP to AMP by phosphodiesterase (PDE) is responsible for adenosine production referred to as the cAMP-adenosine pathway [73]. In addition, adenosine can be produced from S-adenosylhomocysteine (SAH) via SAH hydrolase [21, 82]. Once being released extracellularly, ATP is degraded to
ADP and AMP through the continuous action of NTPDase 1 (CD39) or possibly other NTDPases [119, 124]. Adenosine is then generated from AMP derived from both ATP and cAMP pathways via CD73 [73] (Fig. 1).

Alteration of the regulatory enzyme activity under (patho) physiological conditions or in response to pharmacological stimuli can affect adenosine levels and subsequently the ARmediated vascular responses. Physical training may increase cytoplasmic 5'-nucleosidase and adenosine deaminase activity, thereby affecting adenosine concentration [46]. 5'-nucleosidase activity was thought to be inhibited during ischemia or hypoxia [29]. However, the net adenosine concentration was not measured. In a setting of reduced tissue oxygenation, the adenosine level can be elevated more than the AMP level likely via decreased activity of adenosine kinase [19]. Upon $\beta$-adrenergic stimulation, SAH-hydrolase was inhibited via a calcium-dependent mechanism [90], while CD73 activity was increased [32]. Hypoxia can also increase CD73 activity resulting in increased extracellular cardiac adenosine production [33]. $\alpha 1$-adrenergic stimulation, nitric oxide (NO)-donors and 8-bromo-cGMP could stimulate PKC leading to increased activity of CD73 [4, 65]. Pharmacological inhibition of adenosine deaminase and kinase in perfused mouse hearts resulted in a significant increase in coronary flow [93].

Adenosine can diffuse across cell membranes to maintain the balance between intracellular and extracellular adenosine concentrations. Extracellular adenosine is rapidly taken up by the cells via both sodium-dependent (concentrative nucleoside transporter: CNT) and sodium-independent transporters (equilibrative nucleoside transporter: ENT) for subsequent metabolism [50, 51, 53]. Further, adenosine can pass through the plasma membrane of these cells and be used intracellularly [73]. Once taken up, e.g., by the endothelial cells, adenosine is phosphorylated by adenosine kinase to form AMP or degraded to inosine by adenosine deaminase (ADA) [73] (Fig. 1). Both ENT and CNT are expressed in the heart and vessel [53]. However, ENT1 and ENT2 are the best-characterized transporters for adenosine uptake in the cardiovascular system [50]. Existing evidence has shown that targeting ENT contributes to coronary vasodilation [7, 39]. ENT1 and ENT2 are the predominant nucleoside transporters of the vascular endothelium with an approximate expression of ENT1 twice as high as that of ENT2 [51]. The human ENT1 and ENT2 differ in their sensitivities to inhibition by coronary vasodilators such as dipyridamole, dilazep and draflazine, with ENT1 being $\approx 100$ - to 1000 -fold more sensitive than ENT2 [104].

However, there are several limitations in our current understanding of adenosine metabolism. The mechanisms underlying the regulation of these enzymes and transporters are not fully understood, which deserves further investigations. In addition, more studies are needed using human 


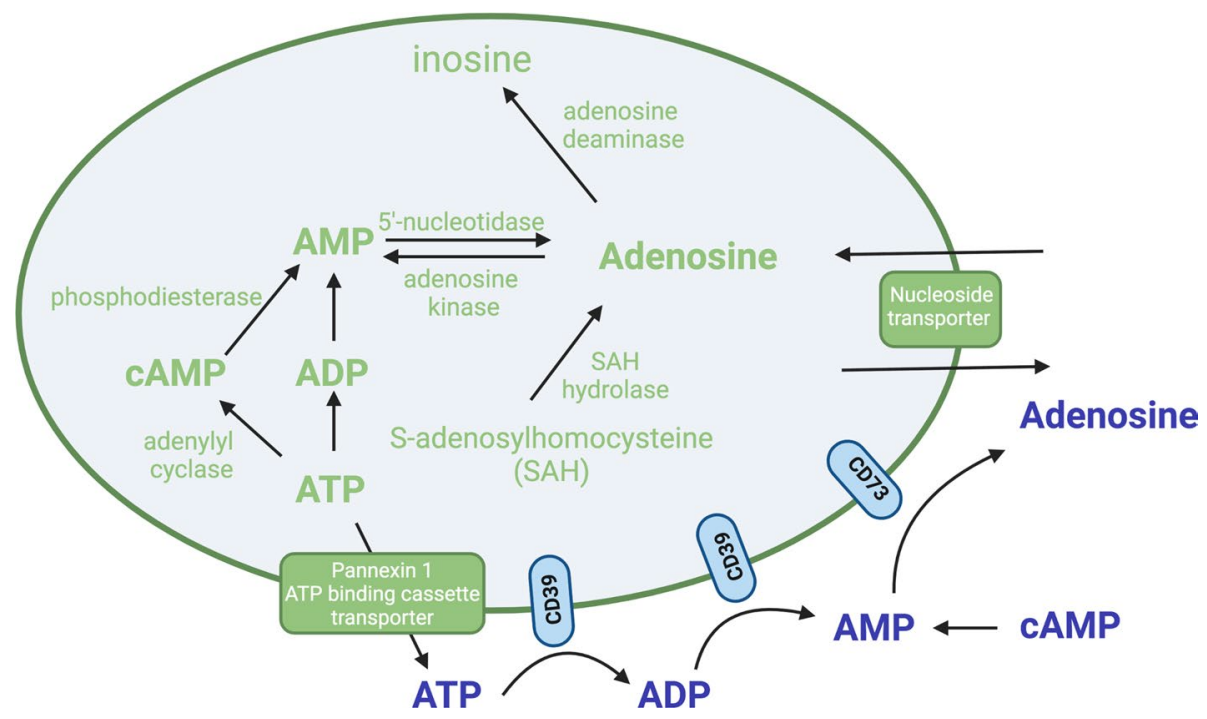

Fig. 1 Adenosine generation and metabolism. Adenosine can be formed intracellularly from ATP, ADP or adenosine monophosphate (AMP) by cytoplasmic 5'-nucleosidase activity. The conversion of cAMP to AMP by phosphodiesterase is responsible for adenosine production referring as the cAMP-adenosine pathway. In addition, adenosine can be produced from S-adenosylhomocysteine (SAH) via SAH hydrolase. Once ATP is released extracellularly through pannexin 1 channels or ATP binding cassette transporter, ATP is

tissues, as there are species differences with respect to adenosine metabolism [20]. Finally, how altered enzyme activity and adenosine concentration affects sensitivity and activation of ARs in coronary microcirculation remains poorly elucidated. For more details on adenosine metabolism, the reader is referred to several excellent review articles $[20$, 81].

\section{Adenosine-mediated actions in physiological conditions}

\section{Involvement of ARs in coronary microvascular tone control}

Adenosine is a potent coronary vasodilator in all species studied, including human $[15,60,69,109,126]$. It can arise directly from cardiomyocytes after intracellular breakdown of ATP and after extracellular breakdown of ATP released from endothelial cells and erythrocytes [71]. The involvement of ARs in adenosine-mediated coronary vasodilation is species dependent. Several lines of evidence have shown that both $\mathrm{A}_{2 \mathrm{~A}} \mathrm{R}$ and $\mathrm{A}_{2 \mathrm{~B}} \mathrm{R}$ mediate exogenous adenosineinduced coronary vasodilation in mice $[59,86,93]$, while $\mathrm{A}_{2 \mathrm{~A}} \mathrm{R}$ is the predominant receptor subtype contributing to coronary vasodilation in swine and dogs $[9,35,52,125]$. Involvement of ARs in human coronary vascular tone is not consistent. Activation of $\mathrm{A}_{2 \mathrm{~A}} \mathrm{R}$ has been shown to regulate human coronary vascular tone [79], whereas another study degraded to ADP and AMP mainly through the continuous action of CD39. Adenosine is then generated from AMP derived from both ATP and cAMP pathways via CD73. Extracellular adenosine is rapidly taken up by the cells via nucleoside transporters for subsequent metabolism. Adenosine is then phosphorylated in the cells by adenosine kinase to form AMP or degraded to inosine by adenosine deaminase

indicates an involvement of $\mathrm{A}_{2 \mathrm{~B}} \mathrm{R}$ in adenosine-induced relaxation in small arteries isolated from human [42]. ARs also interact with each other to regulate coronary vascular tone. Both $A_{1} R$ and $A_{3} R$ have been found to negatively modulate coronary vasodilation induced by $\mathrm{A}_{2 \mathrm{~A}} \mathrm{R}$ and/or $A_{2 B} R$ activation $[92,95]$. The $A_{2 B} R$ expression is upregulated in coronary arteries isolated from mice lacking $A_{2 A} R$. As a functional consequence, the $\mathrm{A}_{2 \mathrm{~B}} \mathrm{R}$-mediated increase in coronary flow is enhanced in mice lacking $A_{2 A} R$ [96]. Further, the $A_{2 A} R$-mediated increase in coronary flow is enhanced in mice lacking $A_{2 B} R$ [78] (Fig. 2). Whether ARs play a significant role in the regulation of coronary basal tone remains controversial. In isolated rat hearts, the coronary baseline flow is significantly reduced by non-selective $A R$ inhibition [49]. $A_{2 A} R$ activation has been observed to contribute to coronary basal NO release and basal tone in isolated hearts of mice [28, 117, 120] (Fig. 2). In contrast, the effect of AR blockade on coronary blood flow in vivo is rather small in human [25, 26] and swine [24], and even absent in dogs and mice [5, 99, 115].

As mentioned earlier, upon induction of hypoxia or ischemia in various tissues, adenosine together with ATP and ADP is released from cells or tissues, all of which significantly contribute to reactive hyperemia $[68,81]$. It has been proposed that adenosine and adenosine-mediated ARs predominantly account for the mid- to late-phase of reactive hyperemia [68]. Existing evidence demonstrates that 


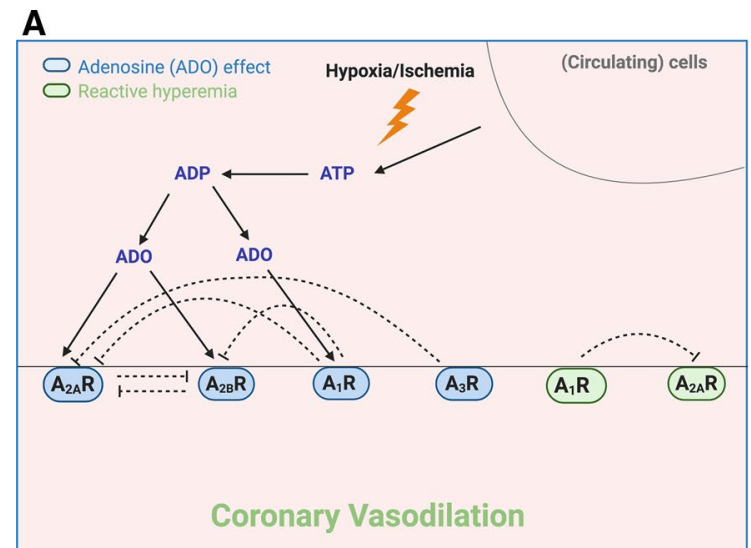

B
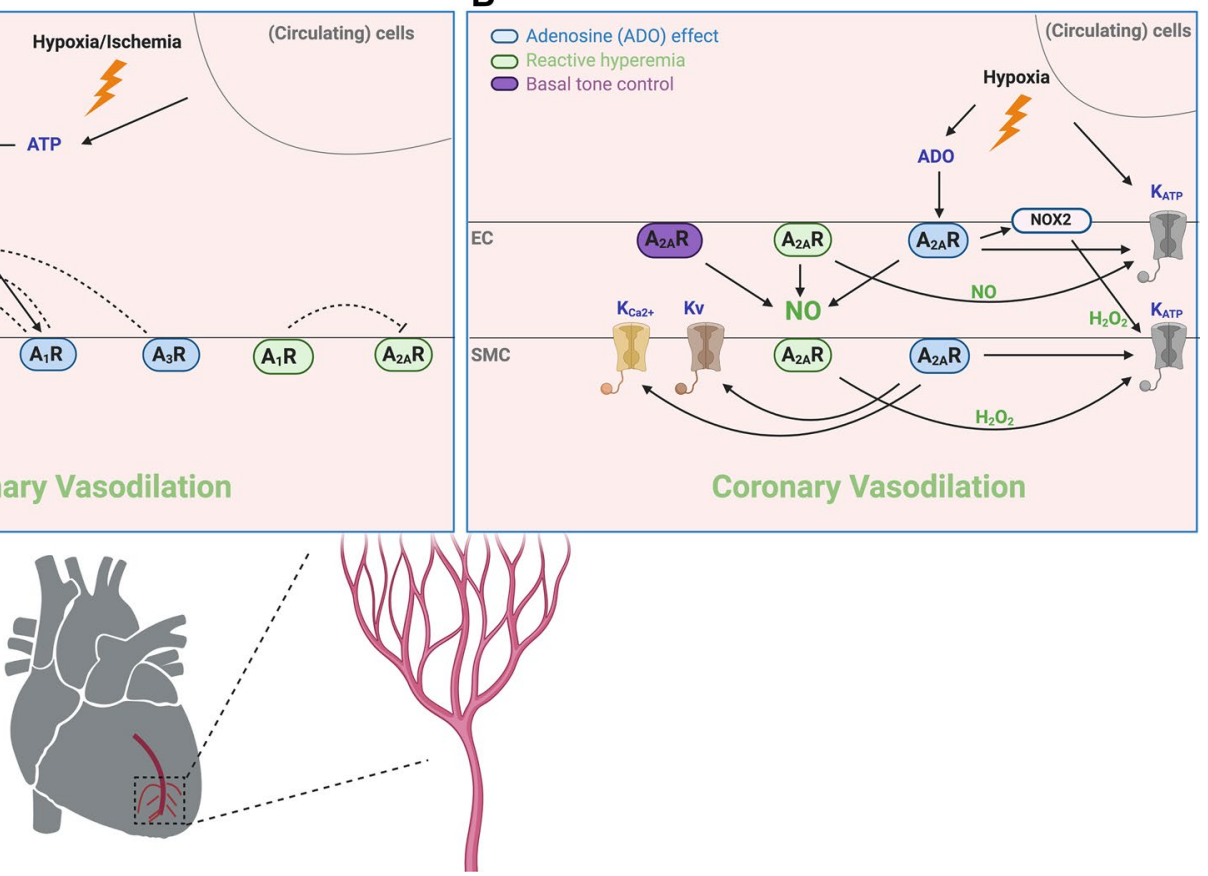

Fig. 2 Adenosine and adenosine receptor (AR)-mediated action in coronary microcirculation in physiology. a Adenosine is generated via extracellular breakdown of ATP released from various cells upon stimulation like hypoxia or ischemia. Adenosine-mediated coronary microvascular tone is mainly through activation of $A_{2 A} R$ and $A_{2 B} R$. $A_{2 A} R$ and $A_{2 B} R$ can compensate for each other, while $A_{1} R$ and $A_{3} R$ negatively modulate the $\mathrm{A}_{2 \mathrm{~A}} \mathrm{R}$ - and $\mathrm{A}_{2 \mathrm{~B}} \mathrm{R}$-mediated coronary vasodilation. $A_{2 A} R$ plays a role in coronary reactive hyperemia. $A_{1} R$ negatively modulates coronary reactive hyperemia mediated by $A_{2 A} R$. b There are endothelium-dependent and -independent regulations of adenosine-mediated coronary microvascular function. Nitric oxide

activation of $\mathrm{A}_{2 \mathrm{~A}} \mathrm{R}$ plays a pivotal role in reactive hyperemia in mice and dogs $[9,86,117,122]$. Other receptors play a lesser role. For instance, $A_{1} R$ has been shown to negatively modulate coronary reactive hyperemia mediated by $\mathrm{A}_{2 \mathrm{~A}} \mathrm{R}$ [122] (Fig. 2). $A_{2 B}$ R seems not to be involved in coronary reactive hyperemia [86, 122]. There is also evidence showing that adenosine is unlikely to be involved in coronary reactive hyperemia [10, 22].

Adenosine levels (calculated) do not increase enough to reach the concentration threshold to cause coronary vasodilation with increasing exercise intensity in human, swine and dogs $[24,100]$, and there is no evidence for increased myocardial interstitial levels of adenosine following adenosine receptor blockade $[100,115]$. No involvement of adenosine or $\mathrm{A}_{2 \mathrm{~A}} \mathrm{R}$ has also been observed in a mouse model with pacing-induced coronary hyperemia [121]. These findings indicate that adenosine is not mandatory for coronary metabolic hyperemia.

Existing evidence demonstrated divergent effects induced by activation of $A_{1} R$ and $A_{3} R$ on coronary microvascular
(NO) is involved in $\mathrm{A}_{2 \mathrm{~A}} \mathrm{R}$-mediated basal tone control and reactive hyperemia, as well as adenosine-mediated $\mathrm{A}_{2 \mathrm{~A}} \mathrm{R}$ activation. $\mathrm{NO}$ is also involved in $\mathrm{A}_{2 \mathrm{~A}} \mathrm{R}-\mathrm{K}_{\mathrm{ATP}}$ axis for reactive hyperemia. Activation of $\mathrm{A}_{2 \mathrm{~A}} \mathrm{R}$ can stimulate NADPH oxidase $2\left(\mathrm{NOX}_{2}\right)$ resulting in $\mathrm{H}_{2} \mathrm{O}_{2}$ production, which leads to smooth muscle cell (SMC) $\mathrm{K}_{\mathrm{ATP}}$ opening and coronary vasodilation. Activation of $\mathrm{A}_{2 \mathrm{~A}} \mathrm{R}$ by reactive hyperemia also involves downstream $\mathrm{H}_{2} \mathrm{O}_{2}-\mathrm{K}_{\text {ATP }}$ axis accounting for coronary vasodilation. Hypoxia can directly activate $\mathrm{K}_{\mathrm{ATP}}$ channels. Involvement of SMC Kv and $\mathrm{K}_{\mathrm{Ca} 2+}$ is coupled to activation of $\mathrm{A}_{2 \mathrm{~A}} \mathrm{R}$. EC endothelial cells

function. Vasodilator effect mediated by $\mathrm{A}_{1} \mathrm{R}$ and $\mathrm{A}_{3} \mathrm{R}$ has been evidenced by the $A_{1} R$-induced vasodilation in canine coronary microcirculation [16] and the $\mathrm{A}_{3} \mathrm{R}$-produced coronary vasodilation in isolated rat hearts $[40,76]$. In contrast, $A_{1} R$ antagonism augments the sensitivity to adenosine in isolated human coronary arterioles [79]. Further, both $A_{1} R$ and $A_{3} R$ have been found to negatively modulate coronary vasodilation induced by $A_{2 A} R$ and/or $A_{2 B} R$ activation in isolated mouse hearts $[92,95]$, and $A_{1} R$ counteracts the $\mathrm{A}_{2 \mathrm{~A}} \mathrm{R}$-mediated coronary reactive hyperemia [122] (Fig. 2).

\section{Endothelium-dependent and -independent regulation}

It has been suggested that both $\mathrm{A}_{2 \mathrm{~A}} \mathrm{R}$ and $\mathrm{A}_{2 \mathrm{~B}} \mathrm{R}$ mediate endothelium-dependent coronary relaxation and $\mathrm{NO}$ release from coronary artery endothelium [1]. Indeed, adenosine5 '-N-ethylcarboxamide (NECA), a nonselective adenosine agonist, and 2-[p-(2-carboxyethyl)] phenylethyl-amino-5'-Nethylcarboxamidoadenosine (CGS-21680), a selective $A_{2 A} R$ agonist, produced relaxation in isolated porcine coronary 
small arteries, which were attenuated by the endotheliumdenudation or NO synthase inhibition [34]. Using two different NO synthase inhibitors L-NAME and L-NMA in isolated hearts from wild-type (WT) and $\mathrm{A}_{2 \mathrm{~A}} \mathrm{R}$ KO mice, both inhibitors attenuated the NECA- or CGS-21680-induced increases in coronary flow in WT, but not $\mathrm{A}_{2 \mathrm{~A}} \mathrm{R} \mathrm{KO}$ mice, indicating a role for $\mathrm{NO}$ in the $\mathrm{A}_{2 \mathrm{~A}} \mathrm{R}$-mediated coronary vasodilation [96]. NO blockade or endothelium denudation also attenuated adenosine-induced vasodilation in porcine coronary arterioles [44]. Interestingly, adenosine- $\mathrm{A}_{2 \mathrm{~A}} \mathrm{R}$ pathway has been shown to regulate coronary basal tone through $\mathrm{NO}$ release in isolated mouse hearts [120]. There is also evidence showing that $\mathrm{NO}$ release is in part triggered by $\mathrm{A}_{2 \mathrm{~A}} \mathrm{R}$ accounting for reactive hyperemia in mice [117]. The role of $\mathrm{A}_{2 \mathrm{~B}} \mathrm{R}$ in $\mathrm{NO}$ release remains to be determined.

In contrast, many other studies have observed that adenosine mediates endothelium-independent relaxation in coronary microvasculature. Thus, adenosine-induced vasodilation in human coronary small arteries was not affected by endothelium denudation [79] or NO blockade [42]. NO synthase inhibition failed to affect adenosine-induced vasodilation in canine coronary arterioles [41]. Endogenous adenosine and $\mathrm{NO}$ work in a parallel manner to regulate vascular tone in isolated canine coronary small arteries [116]. NO does not contribute to the $\mathrm{A}_{2 \mathrm{~A}} \mathrm{R}$-mediated increase in reactive hyperemia in $A_{1} R$ KO mice [122]. Numerous pieces of evidence obtained in denuded porcine coronary small arteries clearly demonstrated that $\mathrm{A}_{2 \mathrm{~A}} \mathrm{R}$ plays a predominant role in endothelial-independent coronary vasodilation, while $\mathrm{A}_{2 \mathrm{~B}} \mathrm{R}$ may play a minor role $[91,98,125]$. The discrepancies on the role of endothelium in the adenosine-mediated coronary microvascular regulation are not readily explained, but may be determined by the different expression and distribution of ARs between the endothelium and smooth muscle cells in the different vascular segments of the microcirculation. It may also depend on different species studied, as NO seems to be involved in adenosine-induced coronary vasodilation in swine, but not dogs [41]. Further studies are warranted to address this issue.

\section{Post-receptor pathways and end-effectors}

The coronary microvascular tone is ultimately determined by the interaction between actin and myosin in the vascular smooth muscle cells. This is regulated by the intracellular $\mathrm{Ca}^{2+}$ concentration. Opening status of one of the important modes voltage-operated $\mathrm{Ca}^{2+}$ channels in vascular smooth muscle is regulated by membrane potential, which in turn is determined by the activation of $\mathrm{K}^{+}$channels [24]. Many vasoactive substances including $\mathrm{H}_{2} \mathrm{O}_{2}$ influence coronary microvascular function through $\mathrm{K}^{+}$channels $[64,75,78$, $86,118]$. The limited evidence regarding the mechanisms is pointed to a possible activation of both transcription and translation of $\mathrm{K}^{+}$channels located at the plasma membrane of the coronary smooth muscle cells [64]. The three main types of $\mathrm{K}^{+}$channels that have been investigated in relation to regulation of coronary vasomotor tone are $\mathrm{K}_{\mathrm{ATP}}, \mathrm{K}_{\mathrm{Ca} 2+}$ and $\mathrm{K}_{\mathrm{V}}$ channels [23]. Despite information indicating that adenosine receptors and $\mathrm{K}_{\mathrm{ATP}}$ work as parallel vasodilator pathways to control coronary blood flow in swine [56], both $\mathrm{A}_{2 \mathrm{~A}} \mathrm{R}$ - and $\mathrm{A}_{2 \mathrm{~B}} \mathrm{R}$-mediated increase in coronary flow in isolated mouse hearts have been observed to be through activation of $K_{\text {ATP }}$ channels [78]. The adenosine/ $A_{2 A} R$ stimulation- or the adenosine analogue-induced relaxation in isolated porcine coronary arterioles or the $\mathrm{A}_{2 \mathrm{~A}} \mathrm{R}$-induced increase in coronary blood flow in open-chest dogs is mediated via activation of $\mathrm{K}_{\mathrm{ATP}}$ channels [8, 9, 34]. Adenosine has been shown to potentiate the flow-mediated dilation in porcine coronary arterioles via activation of $\mathrm{K}_{\mathrm{ATP}}$ channels in endothelium [44]. There is $\mathrm{NO}$ and $\mathrm{K}_{\mathrm{ATP}}$ channel-dependent effects of $A_{2 A} R$ contributing to reactive hyperemia in mouse [117]. Of further interest, recent evidence has shown that $\mathrm{A}_{2 \mathrm{~A}} \mathrm{R}$ activation promotes NADPH oxidase 2-derived reactive oxygen species and subsequently leads to $\mathrm{H}_{2} \mathrm{O}_{2}$ production contributing to the increase in coronary flow in isolated mouse hearts [126]. The interaction between $A_{2 A} R$, $\mathrm{H}_{2} \mathrm{O}_{2}$ and $\mathrm{K}_{\text {ATP }}$ has been demonstrated in delicate models of $\mathrm{A}_{2 \mathrm{~A}} \mathrm{R} \mathrm{KO}$ and $\mathrm{A}_{2 \mathrm{~A}} \mathrm{R} / \mathrm{A}_{2 \mathrm{~B}} \mathrm{R}$ double $\mathrm{KO}$ mice. Thus, patchclamp experiments demonstrated that adenosine can activate glibenclamide-sensitive $\mathrm{K}_{\mathrm{ATP}}$ current in smooth muscle cells from WT, but not $A_{2 A} R$ KO or $A_{2 A} R / A_{2 B} R$ double $K O$ mice [86]. $\mathrm{H}_{2} \mathrm{O}_{2}$ can activate $\mathrm{K}_{\text {ATP }}$ current in smooth muscle cells [86]. Further, adenosine-mediated increase in coronary flow is blunted by catalase, while $\mathrm{H}_{2} \mathrm{O}_{2}$ increases coronary flow which is attenuated by the $\mathrm{K}_{\mathrm{ATP}}$ blocker glibenclamide [86]. Finally, both $\mathrm{H}_{2} \mathrm{O}_{2}$ and $\mathrm{K}_{\text {ATP }}$ activation are involved in $\mathrm{A}_{2 \mathrm{~A}} \mathrm{R}$-mediated coronary reactive hyperemia $[86,122]$. Altogether, these observations indicate that adenosine-mediated $\mathrm{A}_{2 \mathrm{~A}} \mathrm{R}$ is coupled to smooth muscle $\mathrm{K}_{\mathrm{ATP}}$ channels in coronary reactive hyperemia in mice via the production of $\mathrm{H}_{2} \mathrm{O}_{2}$ as a signaling intermediate. Earlier studies have also shown an involvement of $\mathrm{K}_{\mathrm{ATP}}$ channels in hypoxia-induced coronary vasodilation as well as dipyridamole-mediated increase in coronary vasodilation in perfused guinea pig hearts [18, 106], suggesting that adenosine could hyperpolarize smooth muscle cell membrane by opening $\mathrm{K}_{\mathrm{ATP}}$ channels under hypoxic condition.

There is also evidence showing the involvement of $\mathrm{K}_{\mathrm{V}}$ and $\mathrm{K}_{\mathrm{Ca} 2+}$ channels in adenosine- or the $\mathrm{A}_{2 \mathrm{~A}} \mathrm{R}$ agonist-mediated coronary vasodilation. Adenosine-mediated increases in coronary blood flow in dogs and relaxation in isolated canine coronary arteries, the adenosine analogue-induced relaxation in isolated porcine coronary arterioles, as well as the adenosine/the $\mathrm{A}_{2 \mathrm{~A}} \mathrm{R}$ agonist-induced relaxation in coronary arteries isolated from rats are attenuated by $\mathrm{K}_{\mathrm{V}}$ channel inhibition [8, 9, 22, 43]. Moreover, adenosine-mediated 
vasodilation in pressurized human and canine coronary small arteries and in perfused rat hearts were blunted by $\mathrm{K}_{\mathrm{Ca} 2+}$ channel inhibition [11, 58, 79].

Collectively, adenosine-mediated coronary microvascular tone and reactive hyperemia are through complex mechanisms mainly involving $\mathrm{A}_{2 \mathrm{~A}} \mathrm{R}$ activation on both endothelial and smooth muscle cells, but also involving the interaction of different ARs (Fig. 2). Regarding the post-receptor mechanism, $\mathrm{K}_{\mathrm{ATP}}, \mathrm{K}_{\mathrm{V}}$ and $\mathrm{K}_{\mathrm{Ca} 2+}$ channels appear to act as final effectors for the adenosine-mediated coronary microvascular tone regulation. However, the mechanisms underlying how adenosine or the $\mathrm{A}_{2 \mathrm{~A}} \mathrm{R}$-mediated coronary vasodilation activates $\mathrm{H}_{2} \mathrm{O}_{2}-\mathrm{K}_{\text {ATP }}$ axis remains incompletely understood. Moreover, whether adenosine- $\mathrm{H}_{2} \mathrm{O}_{2}-\mathrm{K}_{\text {ATP }}$ axis can be extrapolated to human condition deserves further investigations. Table 1 summarizes important evidence regarding the role of adenosine- and AR-mediated actions in coronary microcirculation in physiology.

\section{Adenosine and adenosine receptor-mediated actions in pathological conditions}

\section{Hypertension}

Hypertension is associated with structural and functional abnormalities in coronary microcirculation including coronary endothelial cell dysfunction, coronary microvascular remodeling and an impaired coronary flow reserve induced by adenosine observed in both human and animals [62, 105]. Arterial hypertension can lead to an increase in the vascular pericyte coverage, which is interestingly not accompanied by a gain in capillary density [127]. In addition, this cell type also undergoes a transformation into a more vascular smooth muscle cell like phenotype showing a more contractile property [127].

Both adenosine and the selective $\mathrm{A}_{2 \mathrm{~A}} \mathrm{R}$ agonist produce concentration-dependent relaxation of coronary arteries isolated from control rats via activation of $\mathrm{Kv}_{7}$ channels but not hypertensive rats [43]. There is downregulation of $\mathrm{A}_{3} \mathrm{R}$ expression and the $\mathrm{A}_{3} \mathrm{R}$-mediated coronary vasodilation in perfused hearts from spontaneously hypertensive rats [38]. In hypertensive swine, the transmural spatial density of microvessels is twice as much as in normotensive animals, and myocardial levels and expression of endotheliumderived growth factors, e.g., FGF (in vascular smooth muscle cells and myocytes) and VEGF (in endothelial cells) are significantly increased. Functionally, the increase in blood volume and myocardial blood flow in response to intravenous adenosine application was blunted in these animals [74]. It seems that activation of downstream potassium channels plays a role. In high-salt diet-induced hypertensive rats, application of nicorandil, an activator of $\mathrm{K}_{\text {ATP }}$ channels, restores NO synthase and attenuates enhanced VEGF and FGF gene expression resulting in coronary capillary and arteriolar growth [114]. These findings suggest that $A_{2 A} R$, $\mathrm{A}_{3} \mathrm{R}$ and potential downstream potassium channels might play a crucial role in coronary microvascular dysfunction in hypertension and potentially set a new strategy to pharmacological manipulation of coronary microvascular function by applying agonists stimulating these components (Table 2).

\section{Diabetes}

Diabetes is an important risk factor for the development of cardiovascular disease including atherosclerosis and ischemic heart disease. The increased morbidity and mortality are significantly attributed to diabetes-induced microvascular dysfunction in the heart [119].

The coronary flow in hearts isolated from type 1 diabetic mice is observed to be significantly increased by the stimulation of the non-selective agonist of ARs and the selective $\mathrm{A}_{2 \mathrm{~A}} \mathrm{R}$ agonist. In addition, in vivo injection of the $\mathrm{A}_{2 \mathrm{~A}} \mathrm{R}$ agonist enhances the efficiency in increasing coronary flow in type 1 diabetic mice [45]. The functional observations are in accordance with the increased $\mathrm{A}_{2 \mathrm{~A}} \mathrm{R}$ expression in coronary arteries as compared to non-diabetic control mice [45]. In contrast, the coronary flow in response to adenosine is significantly blunted in isolated hearts of type 2 diabetic GotoKakizaki (GK) rats as compared to age-matched control rats [58]. The impaired adenosine-induced coronary flow in GK rats can be restored by endothelial $\mathrm{K}_{\mathrm{Ca} 2+}$ opening [58]. In obese rats with insulin resistance, the coronary microvascular perfusion is impaired in response to adenosine infusion [102]. A similar clinical observation was found in a recent study where the adenosine-induced coronary flow reserve is blunted in type 2 diabetic patients without obstructive coronary artery disease [48] (Table 2). The different responses to adenosine stimulation may be due to different etiologies of diabetes, which warrants further investigations.

In a swine model with early-stage metabolic syndrome and hyperglycemia, despite both adenosine-induced increase in coronary blood flow in vivo and the adenosine analogue-mediated relaxation in isolated coronary arterioles did not differ from control swine [8], there was a shift from the $\mathrm{A}_{2 \mathrm{~A}} \mathrm{R}$-mediated coronary relaxation to enhanced $\mathrm{A}_{2 \mathrm{~B}} \mathrm{R}$-mediated coronary relaxation in swine with earlystage metabolic syndrome [8] (Table 2). However, the $\mathrm{A}_{2 \mathrm{~B}} \mathrm{R}$ expression level was lower in coronary arterioles isolated from swine with metabolic syndrome. This may suggest that the sensitivity of $\mathrm{A}_{2 \mathrm{~B}} \mathrm{R}$ upon stimulation by the adenosine analogue is increased thereby maintaining the coronary blood flow [8]. Moreover, the involvement of $\mathrm{K}_{\mathrm{v}}$ channels in AR-mediated coronary relaxation was not affected by earlystage metabolic syndrome, whereas there was a reduced $\mathrm{K}_{\mathrm{ATP}}$ channel function [8]. Activation of $\mathrm{A}_{2 \mathrm{~A}} \mathrm{R}$ has been shown to be coupled to $\mathrm{K}_{\mathrm{ATP}}$ channel to regulate coronary 


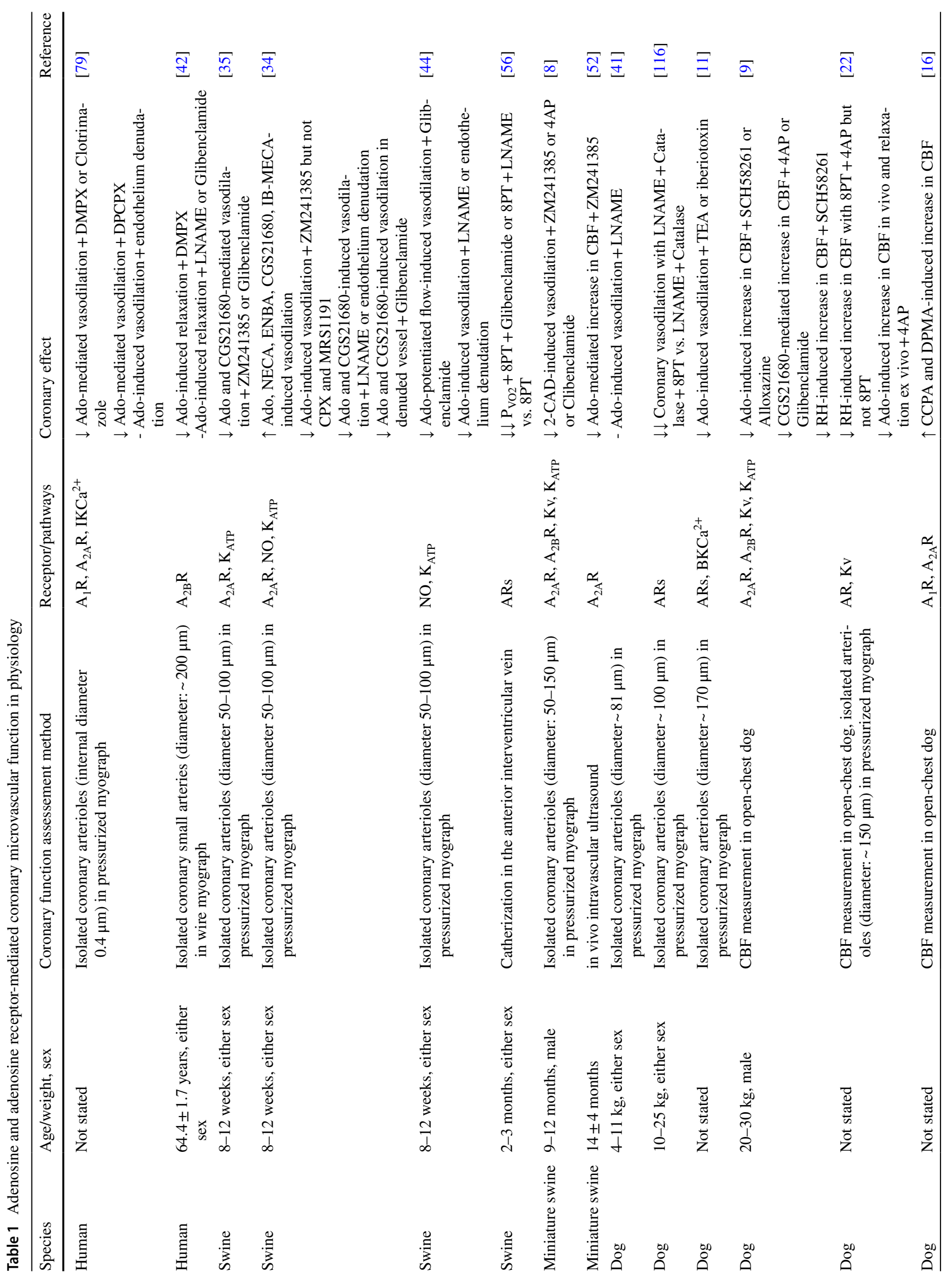




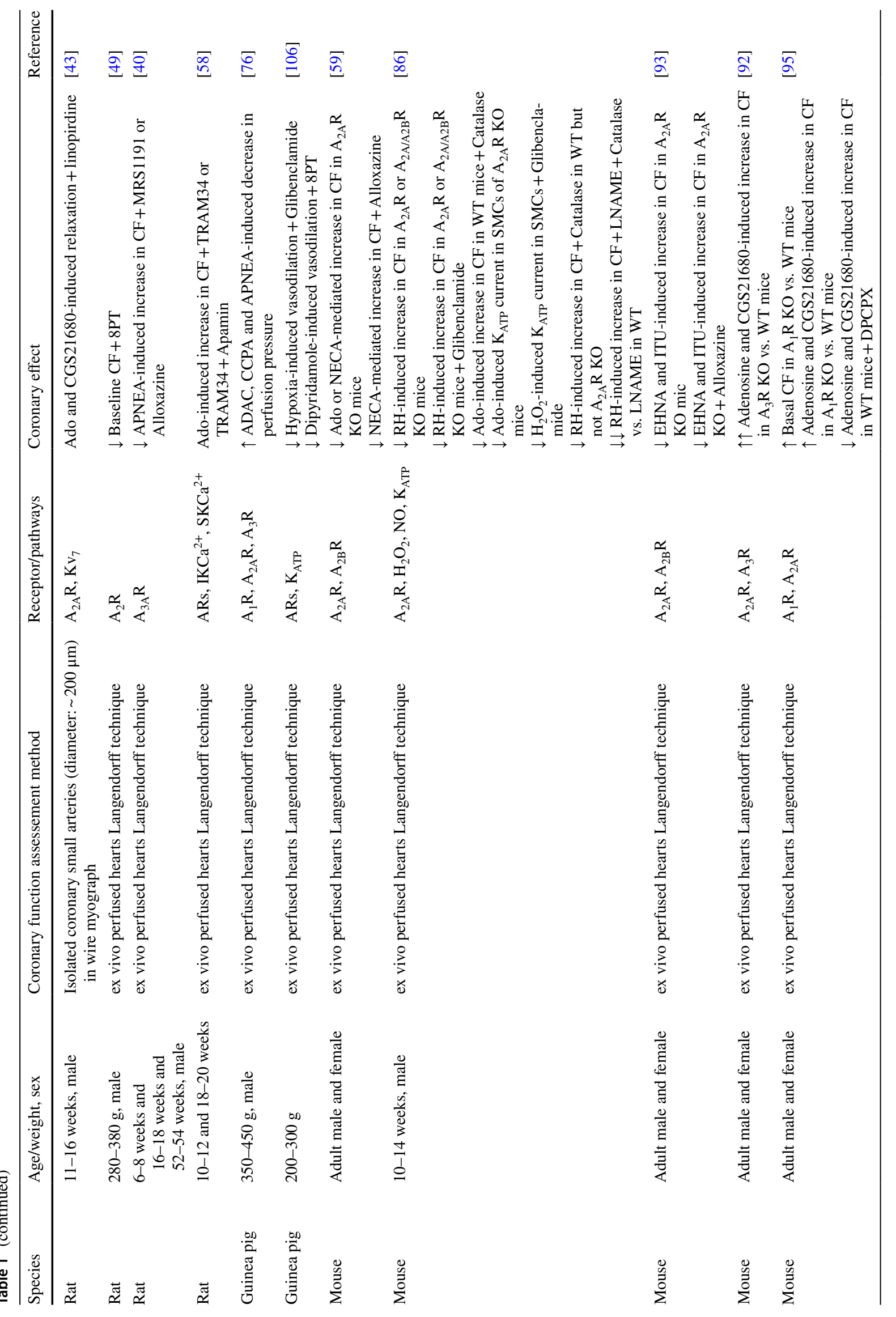




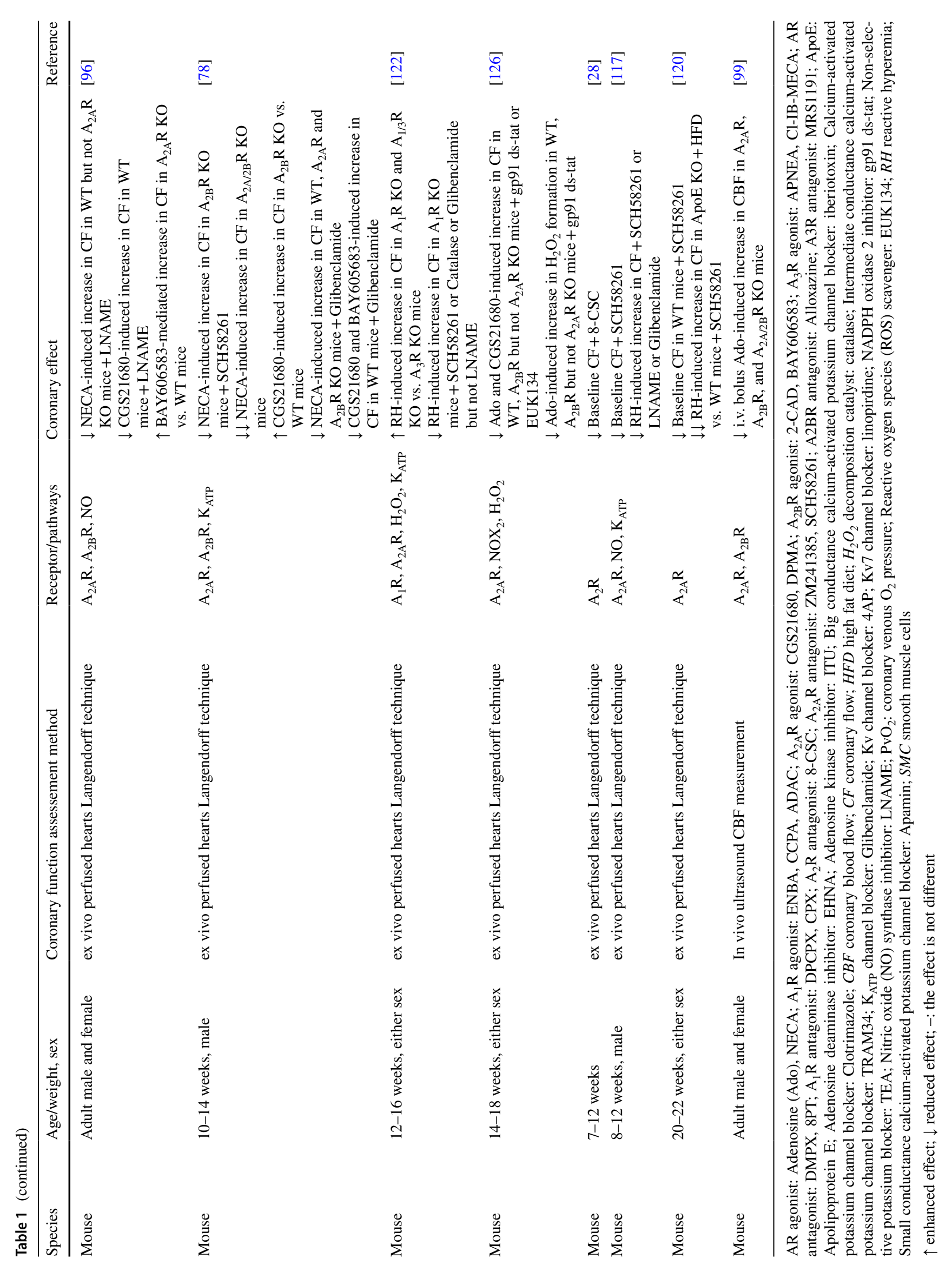


Table 2 Adenosine and adenosine-mediated coronary microvascular function in cardiometabolic disease

\begin{tabular}{|c|c|c|c|c|c|c|}
\hline Disease & Species & Agent & Administration route & Receptor & Coronary effect & Reference \\
\hline \multirow[t]{6}{*}{ Hypertension } & Human & Adenosine & Intracoronary infusion & & Coronary flow reserve $\downarrow$ & [105] \\
\hline & Swine & Adenosine & Intravenous infusion & & $\begin{array}{l}\text { Myocardial microvascular } \\
\text { funciton } \downarrow\end{array}$ & [74] \\
\hline & Rat & Adenosine & $\begin{array}{l}\text { Bolus injection in iso- } \\
\text { lated arteries (diam- } \\
\text { eter: } \sim 200 \mu \mathrm{m})\end{array}$ & & Coronary relaxation $\downarrow$ & [43] \\
\hline & Rat & CGS21680 & $\begin{array}{l}\text { Bolus injection in iso- } \\
\text { lated arteries (diam- } \\
\text { eter: } \sim 200 \mu \mathrm{m})\end{array}$ & $\mathrm{A}_{2 \mathrm{~A}} \mathrm{R}$ & Coronary relaxation $\downarrow$ & [43] \\
\hline & Rat & APNEA & Infusion in isolated hearts & $\mathrm{A}_{3} \mathrm{AR}$ & Coronary relaxation $\downarrow$ & {$[38]$} \\
\hline & Rat & Cl-IB-MECA & Infusion in isolated hearts & $\mathrm{A}_{3} \mathrm{AR}$ & Coronary relaxation $\downarrow$ & {$[38]$} \\
\hline \multirow[t]{6}{*}{ Diabetes } & Human with T2D & Adenosine & Intravenous infusion & & Coronary flow reserve $\downarrow$ & [48] \\
\hline & Swine with MS & Adenosine & Intracoronary infusion & $\mathrm{A}_{2 \mathrm{~B}} \mathrm{R}$ & Coronary blood flow - & [8] \\
\hline & Swine with MS & 2-CAD & $\begin{array}{l}\text { Bolus injection in pres- } \\
\text { surized arterioles (diam- } \\
\text { eter: } 50-150 \mu \mathrm{m})\end{array}$ & $\mathrm{A}_{2 \mathrm{~B}} \mathrm{R}$ & Coronary reaxation - & [8] \\
\hline & $\begin{array}{l}\text { Rats with insulin resist- } \\
\text { ance }\end{array}$ & Adenosine & Intravenous infusion & & $\begin{array}{l}\text { Myocardial microvascular } \\
\text { funciton } \downarrow\end{array}$ & [102] \\
\hline & Mouse with T1D & CGS21680 & Infusion in isolated hearts & $\mathrm{A}_{2 \mathrm{~A}} \mathrm{R}$ & Coronary flow $\uparrow$ & [45] \\
\hline & Mouse with T2D & Adenosine & Infusion in isolated hearts & & Coronary flow $\downarrow$ & {$[58]$} \\
\hline \multirow[t]{4}{*}{ Atherosclerosis } & Human & Adenosine & Intracoronary infusion & & Coronary flow reserve $\downarrow$ & {$[72]$} \\
\hline & Monkey & Adenosine & $\begin{array}{l}\text { Bolus injection in pres- } \\
\text { surized arterioles (diam- } \\
\text { eter } 122-220 \mu \mathrm{m})\end{array}$ & & Coronary relaxation - & [84] \\
\hline & Mouse & CGS21680 & Infusion in isolated hearts & $\mathrm{A}_{2 \mathrm{~A}} \mathrm{R}$ & Coronary flow $\uparrow$ & [97] \\
\hline & Mouse & & $\begin{array}{l}\text { Occlusion in isolated } \\
\text { hearts }\end{array}$ & $\mathrm{A}_{2 \mathrm{~A}} \mathrm{R}$ & Baseline flow and RH $\downarrow$ & {$[120]$} \\
\hline \multirow[t]{3}{*}{ Ischemic heart disease } & Swine & $\mathrm{Up}_{4} \mathrm{~A}$ & $\begin{array}{l}\text { Bolus injection in iso- } \\
\text { lated arteries (diam- } \\
\text { eter } \sim 150 \mu \mathrm{m} \text { ) }\end{array}$ & $\mathrm{A}_{2 \mathrm{~B}} \mathrm{R}$ & Coronary relaxation $\downarrow$ & {$[123]$} \\
\hline & Dog & DPMA & Intravenous infusion & $\mathrm{A}_{2 \mathrm{~A}} \mathrm{R}$ & $\begin{array}{l}\text { Increase in coronary } \\
\text { blood flow } \downarrow\end{array}$ & [16] \\
\hline & Dog & Adenosine & Intracoronary infusion & & $\begin{array}{l}\text { Increase in coronary } \\
\text { flow } \downarrow\end{array}$ & {$[103]$} \\
\hline
\end{tabular}

$\mathrm{A}_{2 \mathrm{~A}} \mathrm{R}$ agonist: CGS21680; DPMA; $\mathrm{A}_{2 \mathrm{~B}} \mathrm{R}$ agonist: 2-CAD; $\mathrm{A}_{3} \mathrm{R}$ agonist: APNEA, Cl-IB-MECA; MS: metabolic syndrome; T1D: type 2 diabetes; T2D: type 2 diabetes

$\uparrow$ enhanced effect, $\downarrow$ reduced effect; - the effect is not different

microcirculation [78, 86]. The reduced $\mathrm{K}_{\mathrm{ATP}}$ function by early-stage metabolic syndrome can be affected by the shift of vasodilator $\mathrm{A}_{2 \mathrm{~A}} \mathrm{R}$.

\section{Atherosclerosis}

Atherosclerosis is generally predominant in large coronary arteries. However, long-term exposure to hypercholesterolemia can activate endothelial cells and thus induce leukocyte recruitment, oxidative stress and loss of pericytes in the microcirculation [12]. This alteration may lead to capillary rarefication due to a decrease in capillary surface area resulting in a dysfunctional downstream vessel system and a drastic decrease in overall capillary diameter [127].
Moreover, in atherosclerotic areas, relative anoxia, inflammation and oxidative stress promote release of angiogenic factors resulting in angiogenesis and vasculogenesis [57]. It has been estimated that local adenosine may mediate $50-70 \%$ of the angiogenic response to hypoxia/ischemia [2]. $A_{1} R, A_{2 B} R$ and $A_{3} R$ were involved in angiogenesis surroundings and downstream vessels of the atherosclerotic plaque, and $A_{1} R$ and $A_{2 B} R$ were reported to promote endothelial progenitor cell homing to coronary microvascular endothelium for the genesis of capillary networks [77]. Regarding the action of adenosine on vascular tone regulation, the coronary microvascular responses to adenosine are not consistent in atherosclerosis. Low coronary flow reserve after intracoronary adenosine infusion was observed 
in patients with atherosclerosis risk [72]. Reactive hyperemia-induced increase in coronary flow was lower in female atherosclerotic mice, and the less increase in coronary flow was inhibited by the $\mathrm{A}_{2 \mathrm{~A}} \mathrm{R}$ antagonist to a greater extent in atherosclerotic than control groups [120]. In contrast, an enhanced response in coronary flow to $\mathrm{A}_{2 \mathrm{~A}} \mathrm{R}$ stimulation in hyperlipidemic/atherosclerotic mice was reported [97]. It has been suggested that upregulation of $\mathrm{A}_{2 \mathrm{~A}} \mathrm{R}$ is a compensatory mechanism to maintain NO-dependent endothelial function as evaluated by coronary vasodilation in a mouse model of atherosclerosis [120]. One study indicates that responses of isolated coronary arterioles to adenosine are identical in atherosclerotic and control monkeys [84] (Table 2). The experimental evidence may suggest that the diagnosis of coronary artery disease in patients using adenosine as a stimulator can be underestimated.

\section{Ischemic heart disease}

Among complex pathophysiological components, e.g. obstructive coronary atherosclerosis, more and more evidence has shown that coronary microvascular dysfunction significantly plays a role in the etiology of ischemic heart disease [54, 70, 94]. On the other hand, the coronary vasculature itself is also a victim of ischemia-reperfusion injury and myocardial infarction [30, 37]. The majority of experimental and clinical studies have focused on the effects of adenosine more on cardiomyocytes as compared to the coronary vasculature, as dissecting the effects of adenosine or AR activation on the coronary microcirculation from cardiomyocytes is challenging, given the causal relationship between injuries to the coronary vasculature and cardiomyocytes following the myocardial infarction.

Existing data demonstrated that there seems to be a reduced sensitivity to adenosine in the coronary microvasculature in ischemic heart $[103,128]$. the $\mathrm{A}_{2} \mathrm{R}$ agonist-induced coronary vasodilation was attenuated by the ischemia-reperfusion in anesthetized dogs [16]. The AR-, likely $\mathrm{A}_{2 \mathrm{~B}} \mathrm{R}$-mediated relaxation to the novel dinucleotide $\mathrm{Up}_{4} \mathrm{~A}$ in isolated coronary small arteries was found to be blunted in swine with myocardial infarction [123] (Table 2). More studies are needed to further elucidate the specific AR involvement in coronary microvascular function following myocardial infarction and how alteration of AR sensitivity is associated with ischemic heart disease.

\section{Perspective on indirect adenosine modulation as therapeutic strategy}

Adenosine and AR modulations may serve as therapeutic strategy in cardiovascular medicine in two manners. First, both endogenous and exogenous adenosine and adenosine-activated ARs per se have been evaluated in various preclinical and clinical settings. However, the effect of adenosine and AR modulation in myocardial injury and heart failure has shown inconsistent effects on cardiac function and myocardial perfusion. The exact mechanisms are not readily explained, but one possibility may rely on where the modulation takes place. For instance, endogenous generation of interstitial, but not venous adenosine, is critical to protect myocardium against infarction [83, 87], which could be induced by ischemic preconditioning, but not coronary microembolization [87]. Moreover, none of the pharmacological tools targeting ARs that entered clinical trials have emerged as drug candidates due to lower efficacy, kinetics issues or adverse events reported. Better rational design and development of other agonists and antagonists may lead to successful clinical drug candidates in the future. Readers are referred to several review articles on this topic for more details $[14,61,111]$. Second, other drugs can initiate secondary effects through generation of adenosine and activation of AR-mediated signaling. It is important to note that AR-mediated actions may affect both coronary vasculature and cardiomyocytes, making it difficult to separate vascular effect from cardio-protection. This section focuses on the discussion of the indirect adenosine modulation for a potential therapeutic strategy.

An indirect, but clinically important, effect on AR-mediated signaling was recently postulated for ticagrelor [17]. Ticagrelor is the $\mathrm{P} 2 \mathrm{Y}_{12} \mathrm{R}$ antagonist primarily targeting platelets and its application is clinically wellestablished to prevent thromboembolic complications after acute coronary syndrome [107]. Of note, ticagrelor can induce substantial amount of ATP release from erythrocytes via anion channels and target the ENT1 transporter in erythrocytes which inhibits adenosine uptake by erythrocytes $[66,110]$. Together with adenosine degraded from ATP in this pathway, ticagrelor, by targeting erythrocytes, leads to increases in circulating adenosine levels [101]. Considering the beneficial effects of adenosine on cardiovascular function [110], ticagrelor could have pleiotropic effects beyond its platelet inhibitory effects, as treatment with ticagrelor reduced major cardiovascular adverse events (MACE) compared to clopidogrel, another $\mathrm{P}_{2} \mathrm{Y}_{12} \mathrm{R}$ antagonist that does not have impact on erythrocytes for purinergic activation, in patients with acute coronary syndrome [13]. Indeed, increased adenosine concentrations by ticagrelor reduced anti-inflammatory responses, improved vascular function and attenuated ischemia-reperfusion injury [13]. Moreover, ticagrelor significantly enhanced adenosine-increased coronary blood flow in human and adenosine-mediated hyperemia in dogs [101, 112]. Of note, a clinical study evaluating the effects of ticagrelor in stable multivessel ischemic heart disease is ongoing [17]. However, how much adenosine-mediated secondary effect of ticagrelor contributes to overall cardiovascular outcomes remains unclear. 
In addition to ticagrelor, magnesium has been applied in patients for possible treatment of acute myocardial infarction [113]. Evidence has shown that the beneficial effect of magnesium in an animal model of myocardial infarction on the infarct size is by adenosine through enhancement of 5 '-nucleosidase activity [55]. It is of interest to monitor the effect of magnesium on the coronary microvascular function. Further studies are required to better elucidate the extent to which enhanced adenosine responses contribute to the clinical profile of those compounds. More studies aiming at pinpointing ARs and manipulating receptor sensitivity in coronary microvasculature are also needed to evaluate the possible therapeutic potential.

\section{Conclusions and perspectives}

Adenosine is an endogenous purine nucleoside that functions as an extracellular signaling molecule via activation of ARs. Adenosine and adenosine-mediated ARs play a significant role in the regulation of coronary microcirculation in certain conditions in physiology and pathophysiology. Adenosine mediates coronary microvascular tone and reactive hyperemia mainly through $\mathrm{A}_{2 \mathrm{~A}} \mathrm{R}$ activation on both endothelial and smooth muscle cells and also via interaction with other ARs. ARs further activate the downstream effectors including $\mathrm{H}_{2} \mathrm{O}_{2}, \mathrm{~K}_{\mathrm{ATP}}, \mathrm{K}_{\mathrm{V}}$ and $\mathrm{K}_{\mathrm{Ca} 2+}$ channels leading to coronary vasodilation.

Adenosine-mediated AR activation also plays a role in several cardiovascular diseases. Downregulation of $\mathrm{A}_{2 \mathrm{~A}} \mathrm{R}$, $\mathrm{A}_{3} \mathrm{R}$ and potential downstream potassium channels play a crucial role in coronary dysfunction in hypertension. $A_{1} R$, $A_{2 B} R$ and $A_{3} R$ are thought to be involved in the angiogenesis and microvascular growth in coronary atherosclerosis. The coronary microvascular responses to adenosine are not consistent in atherosclerosis, which may underestimate diagnosis of coronary artery disease using adenosine as a stimulator. There is a decreased $\mathrm{A}_{2} \mathrm{R}$ sensitivity in coronary microcirculation after ischemia-reperfusion and myocardial infarction. The adenosine effect on coronary flow regulation in diabetes is not consistent and may depend on the etiology of diabetes. More studies are needed to evaluate the adenosine and AR modulation for the treatment. Indirect modulation of adenosine by a compound like ticagrelor may be of potential for the improvement of coronary microvascular function in certain cardiovascular disorders.

Collectively, there is a complexity of adenosine and ARmediated effects in coronary microcirculation. Many aspects are still not fully understood due to a number of discrepant observations. The discrepancy arises from (1) endogenous adenosine vs. exogenous adenosine effects and adenosine concentration vs. AR sensitivity, (2) different conditions/ stimuli (basal condition, ischemia, hypoxia, exercise/pacing and diseases) and (3) differences in AR expression and distribution in different microvascular segments of different species. Better understanding of these aspects will help with elucidation of the role of adenosine and AR in the regulation of coronary microcirculation and development of novel therapeutic strategies.

Acknowledgment This work was supported by the Swedish Heart and Lung Foundation (20190341 and 20200326) (to ZZ), the Karolinska Institutet Grant (2018-01837 and 2020-02285) (to ZZ), the Loo and Hans Ostermans Stiftelse (2018-01213 and 2020-01209) (to ZZ), and the Lars Hiertas Minne Foundation (FO2018-0156) (to ZZ), the National Key R\&D Program of China (2019YFC1709101) (to YT), the Project First-Class Disciplines Development of Chengdu University of Traditional Chinese Medicine (CZYHW1901) (to YT), the National Natural Science Foundation of China (81904306) (to XC), and the Science and Technology Program of Sichuan Province, China (20GJHZ0036) (to XC). We acknowledge many of those who have made significant contributions to adenosine and coronary microcirculation field that are not included in the present study.

Funding Open access funding provided by Karolinska Institute.

\section{Declarations}

Conflict of interest None.

Open Access This article is licensed under a Creative Commons Attribution 4.0 International License, which permits use, sharing, adaptation, distribution and reproduction in any medium or format, as long as you give appropriate credit to the original author(s) and the source, provide a link to the Creative Commons licence, and indicate if changes were made. The images or other third party material in this article are included in the article's Creative Commons licence, unless indicated otherwise in a credit line to the material. If material is not included in the article's Creative Commons licence and your intended use is not permitted by statutory regulation or exceeds the permitted use, you will need to obtain permission directly from the copyright holder. To view a copy of this licence, visit http://creativecommons.org/licenses/by/4.0/.

\section{References}

1. Abebe W, Hussain T, Olanrewaju H, Mustafa SJ (1995) Role of nitric oxide in adenosine receptor-mediated relaxation of porcine coronary artery. Am J Physiol 269:H1672-1678. https://doi.org/ 10.1152/ajpheart.1995.269.5.H1672

2. Adair TH (2005) Growth regulation of the vascular system: an emerging role for adenosine. Am J Physiol Regul Integr Comp Physiol 289:R283-R296. https://doi.org/10.1152/ajpregu.00840. 2004

3. Ansari HR, Teng B, Nadeem A, Roush KP, Martin KH, Schnermann J, Mustafa SJ (2009) A(1) adenosine receptor-mediated PKC and p42/p44 MAPK signaling in mouse coronary artery smooth muscle cells. Am J Physiol Heart Circ Physiol 297:H1032-1039. https://doi.org/10.1152/ajpheart.00374.2009

4. Ashton KJ, Nilsson U, Willems L, Holmgren K, Headrick JP (2003) Effects of aging and ischemia on adenosine receptor transcription in mouse myocardium. Biochem Biophys Res Commun 312:367-372. https://doi.org/10.1016/j.bbrc.2003.10.127 
5. Bache RJ, Dai XZ, Schwartz JS, Homans DC (1988) Role of adenosine in coronary vasodilation during exercise. Circ Res 62:846-853. https://doi.org/10.1161/01.res.62.4.846

6. Bairey Merz CN, Pepine CJ, Shimokawa H, Berry C (2020) Treatment of coronary microvascular dysfunction. Cardiovasc Res 116:856-870. https://doi.org/10.1093/cvr/cvaa006

7. Belardinelli L, Shryock JC, Snowdy S, Zhang Y, Monopoli A, Lozza G, Ongini E, Olsson RA, Dennis DM (1998) The A2A adenosine receptor mediates coronary vasodilation. J Pharmacol Exp Ther 284:1066-1073

8. Bender SB, Tune JD, Borbouse L, Long X, Sturek M, Laughlin MH (2009) Altered mechanism of adenosine-induced coronary arteriolar dilation in early-stage metabolic syndrome. Exp Biol Med (Maywood) 234:683-692. https://doi.org/10.3181/ 0812-RM-350

9. Berwick ZC, Payne GA, Lynch B, Dick GM, Sturek M, Tune JD (2010) Contribution of adenosine $\mathrm{A}(2 \mathrm{~A})$ and $\mathrm{A}(2 \mathrm{~B})$ receptors to ischemic coronary dilation: role of $\mathrm{K}(\mathrm{V})$ and $\mathrm{K}(\mathrm{ATP})$ channels. Microcirculation 17:600-607. https://doi.org/10.1111/j.15498719.2010.00054.x

10. Bittar N, Pauly TJ (1971) Myocardial reactive hyperemia responses in the dog after aminophylline and lidoflazine. Am J Physiol 220:812-815. https://doi.org/10.1152/ajplegacy.1971. 220.3.812

11. Cabell F, Weiss DS, Price JM (1994) Inhibition of adenosineinduced coronary vasodilation by block of large-conductance $\mathrm{Ca}(2+)$-activated K+ channels. Am J Physiol 267:H1455-1460. https://doi.org/10.1152/ajpheart.1994.267.4.H1455

12. Camare C, Pucelle M, Negre-Salvayre A, Salvayre R (2017) Angiogenesis in the atherosclerotic plaque. Redox Biol 12:1834. https://doi.org/10.1016/j.redox.2017.01.007

13. Cattaneo M, Schulz R, Nylander S (2014) Adenosine-mediated effects of ticagrelor: evidence and potential clinical relevance. $\mathrm{J}$ Am Coll Cardiol 63:2503-2509. https://doi.org/10.1016/j.jacc. 2014.03.031

14. Chen JF, Eltzschig HK, Fredholm BB (2013) Adenosine receptors as drug targets-what are the challenges? Nat Rev Drug Discov 12:265-286. https://doi.org/10.1038/nrd3955

15. Cobbin LB, Einstein R, Maguire MH (1974) Studies on the coronary dilator actions of some adenosine analogues. Br J Pharmacol 50:25-33. https://doi.org/10.1111/j.1476-5381.1974.tb095 89. $\mathrm{x}$

16. Cox BF, Greenland BD, Perrone MH, Merkel LA (1994) Ischaemia/reperfusion selectively attenuates coronary vasodilatation to an adenosine A2- but not to an A1-agonist in the dog. Br J Pharmacol 111:1233-1239. https://doi.org/10.1111/j.1476-5381. 1994.tb14877.x

17. D'Amario D, Restivo A, Leone AM, Vergallo R, Migliaro S, Canonico F, Galli M, Trani C, Burzotta F, Aurigemma C, Niccoli G, Buffon A, Montone RA, Flex A, Franceschi F, Tinelli G, Limbruno U, Francese F, Ceccarelli I, Borovac JA, Porto I, Crea $\mathrm{F}$ (2020) Ticagrelor and preconditioning in patients with stable coronary artery disease (TAPER-S): a randomized pilot clinical trial. Trials 21:192. https://doi.org/10.1186/s13063-020-4116-7

18. Daut J, Maier-Rudolph W, von Beckerath N, Mehrke G, Gunther K, Goedel-Meinen L (1990) Hypoxic dilation of coronary arteries is mediated by ATP-sensitive potassium channels. Science 247:1341-1344. https://doi.org/10.1126/science.2107575

19. Decking UK, Arens S, Schlieper G, Schulze K, Schrader J (1997) Dissociation between adenosine release, MVO2, and energy status in working guinea pig hearts. Am J Physiol 272:H371-381. https://doi.org/10.1152/ajpheart.1997.272.1.H371

20. Deussen A (2000) Metabolic flux rates of adenosine in the heart. Naunyn Schmiedebergs Arch Pharmacol 362:351-363. https:// doi.org/10.1007/s002100000318
21. Deussen A, Lloyd HG, Schrader J (1989) Contribution of S-adenosylhomocysteine to cardiac adenosine formation. J Mol Cell Cardiol 21:773-782. https://doi.org/10.1016/0022-2828(89) 90716-5

22. Dick GM, Bratz IN, Borbouse L, Payne GA, Dincer UD, Knudson JD, Rogers PA, Tune JD (2008) Voltage-dependent K+ channels regulate the duration of reactive hyperemia in the canine coronary circulation. Am J Physiol Heart Circ Physiol 294:H2371-2381. https://doi.org/10.1152/ajpheart.01279.2007

23. Dick GM, Tune JD (2010) Role of potassium channels in coronary vasodilation. Exp Biol Med (Maywood) 235:10-22. https:// doi.org/10.1258/ebm.2009.009201

24. Duncker DJ, Bache RJ, Merkus D (2012) Regulation of coronary resistance vessel tone in response to exercise. J Mol Cell Cardiol 52:802-813. https://doi.org/10.1016/j.yjmcc.2011.10.007

25. Edlund A, Conradsson T, Sollevi A (1995) A role for adenosine in coronary vasoregulation in man. Effects of theophylline and enprofylline. Clin Physiol 15:623-636. https://doi.org/10.1111/j. 1475-097x.1995.tb00549.x

26. Edlund A, Sollevi A (1995) Theophylline increases coronary vascular tone in humans: evidence for a role of endogenous adenosine in flow regulation. Acta Physiol Scand 155:303-311. https://doi.org/10.1111/j.1748-1716.1995.tb09978.x

27. Feoktistov I, Goldstein AE, Ryzhov S, Zeng D, Belardinelli L, Voyno-Yasenetskaya T, Biaggioni I (2002) Differential expression of adenosine receptors in human endothelial cells: role of A2B receptors in angiogenic factor regulation. Circ Res 90:531538. https://doi.org/10.1161/01.res.0000012203.21416.14

28. Flood AJ, Willems L, Headrick JP (2002) Coronary function and adenosine receptor-mediated responses in ischemic-reperfused mouse heart. Cardiovasc Res 55:161-170. https://doi.org/10. 1016/s0008-6363(02)00329-2

29. Gustafson LA, Kroll K (1998) Downregulation of 5'-nucleotidase in rabbit heart during coronary underperfusion. Am J Physiol 274:H529-538. https://doi.org/10.1152/ajpheart.1998. 274.2.H529

30. Hausenloy DJ, Chilian W, Crea F, Davidson SM, Ferdinandy P, Garcia-Dorado D, van Royen N, Schulz R, Heusch G (2019) The coronary circulation in acute myocardial ischaemia/reperfusion injury: a target for cardioprotection. Cardiovasc Res 115:11431155. https://doi.org/10.1093/cvr/cvy286

31. Headrick JP, Ashton KJ, Rose'meyer RB, Peart JN (2013) Cardiovascular adenosine receptors: expression, actions and interactions. Pharmacol Ther 140:92-111. https://doi.org/10.1016/j. pharmthera.2013.06.002

32. Headrick JP, Emerson CS, Berr SS, Berne RM, Matherne GP (1996) Interstitial adenosine and cellular metabolism during beta-adrenergic stimulation of the in situ rabbit heart. Cardiovasc Res 31:699-710

33. Headrick JP, Matherne GP, Berne RM (1992) Myocardial adenosine formation during hypoxia: effects of ecto-5'-nucleotidase inhibition. J Mol Cell Cardiol 24:295-303. https://doi.org/10. 1016/0022-2828(92)93166-h

34. Hein TW, Belardinelli L, Kuo L (1999) Adenosine A(2A) receptors mediate coronary microvascular dilation to adenosine: role of nitric oxide and ATP-sensitive potassium channels. J Pharmacol Exp Ther 291:655-664

35. Hein TW, Wang W, Zoghi B, Muthuchamy M, Kuo L (2001) Functional and molecular characterization of receptor subtypes mediating coronary microvascular dilation to adenosine. J Mol Cell Cardiol 33:271-282. https://doi.org/10.1006/jmcc.2000. 1298

36. Heusch G (2010) Adenosine and maximum coronary vasodilation in humans: myth and misconceptions in the assessment of 
coronary reserve. Basic Res Cardiol 105:1-5. https://doi.org/10. 1007/s00395-009-0074-7

37. Heusch G (2020) Myocardial ischaemia-reperfusion injury and cardioprotection in perspective. Nat Rev Cardiol. https://doi.org/ 10.1038/s41569-020-0403-y

38. Ho MF, Low LM, Rose'Meyer RB (2016) Pharmacology of the Adenosine A3 Receptor in the Vasculature and Essential Hypertension. PLoS ONE 11:e0150021. https://doi.org/10.1371/journ al.pone. 0150021

39. Hyde RJ, Cass CE, Young JD, Baldwin SA (2001) The ENT family of eukaryote nucleoside and nucleobase transporters: recent advances in the investigation of structure/function relationships and the identification of novel isoforms. Mol Membr Biol 18:53-63

40. Jenner TL, Rose'meyer RB (2006) Adenosine A(3) receptor mediated coronary vasodilation in the rat heart: changes that occur with maturation. Mech Ageing Dev 127:264-273. https:// doi.org/10.1016/j.mad.2005.10.005

41. Jones CJ, Kuo L, Davis MJ, DeFily DV, Chilian WM (1995) Role of nitric oxide in the coronary microvascular responses to adenosine and increased metabolic demand. Circulation 91:1807-1813. https://doi.org/10.1161/01.cir.91.6.1807

42. Kemp BK, Cocks TM (1999) Adenosine mediates relaxation of human small resistance-like coronary arteries via $\mathrm{A} 2 \mathrm{~B}$ receptors. Br J Pharmacol 126:1796-1800. https://doi.org/10.1038/sj.bjp. 0702462

43. Khanamiri S, Soltysinska E, Jepps TA, Bentzen BH, Chadha PS, Schmitt N, Greenwood IA, Olesen SP (2013) Contribution of $\mathrm{Kv} 7$ channels to basal coronary flow and active response to ischemia. Hypertension 62:1090-1097. https://doi.org/10.1161/ HYPERTENSIONAHA.113.01244

44. Kuo L, Chancellor JD (1995) Adenosine potentiates flow-induced dilation of coronary arterioles by activating KATP channels in endothelium. Am J Physiol 269:H541-549. https://doi.org/10. 1152/ajpheart.1995.269.2.H541

45. Labazi H, Teng B, Zhou Z, Mustafa SJ (2016) Enhanced A2A adenosine receptor-mediated increase in coronary flow in type I diabetic mice. J Mol Cell Cardiol 90:30-37. https://doi.org/10. 1016/j.yjmcc.2015.11.033

46. Langfort J, Czarnowski D, Pilis W, Wojcik B, Gorski J (1996) Effect of various types of exercise training on 5'-nucleotidase and adenosine deaminase activities in rat heart: influence of a single bout of endurance exercise. Biochem Mol Med 59:28-32. https://doi.org/10.1006/bmme.1996.0060

47. Layland J, Carrick D, Lee M, Oldroyd K, Berry C (2014) Adenosine: physiology, pharmacology, and clinical applications. JACC Cardiovasc Interv 7:581-591. https://doi.org/10.1016/j.jcin.2014. 02.009

48. Levelt E, Piechnik SK, Liu A, Wijesurendra RS, Mahmod M, Ariga R, Francis JM, Greiser A, Clarke K, Neubauer S, Ferreira VM, Karamitsos TD (2017) Adenosine stress CMR T1-mapping detects early microvascular dysfunction in patients with type 2 diabetes mellitus without obstructive coronary artery disease. J Cardiovasc Magn Reson 19:81. https://doi.org/10.1186/ s12968-017-0397-8

49. Lewis CD, Hourani SM (1997) Involvement of functional antagonism in the effects of adenosine antagonists and L-NAME in the rat isolated heart. Gen Pharmacol 29:421-427. https://doi.org/ 10.1016/s0306-3623(96)00466-1

50. Li RW, Yang C, Sit AS, Lin SY, Ho EY, Leung GP (2012) Physiological and pharmacological roles of vascular nucleoside transporters. J Cardiovasc Pharmacol 59:10-15. https://doi.org/10. 1097/FJC.0b013e31820eb788

51. Loffler M, Morote-Garcia JC, Eltzschig SA, Coe IR, Eltzschig HK (2007) Physiological roles of vascular nucleoside transporters. Arterioscler Thromb Vasc Biol 27:1004-1013. https://doi.org/10.1161/ATVBAHA.106.126714

52. Long X, Mokelke EA, Neeb ZP, Alloosh M, Edwards JM, Sturek M (2010) Adenosine receptor regulation of coronary blood flow in Ossabaw miniature swine. J Pharmacol Exp Ther 335:781787. https://doi.org/10.1124/jpet.110.170803

53. Lu H, Chen C, Klaassen C (2004) Tissue distribution of concentrative and equilibrative nucleoside transporters in male and female rats and mice. Drug Metab Dispos 32:1455-1461. https:// doi.org/10.1124/dmd.104.001123

54. Marzilli M, Merz CN, Boden WE, Bonow RO, Capozza PG, Chilian WM, DeMaria AN, Guarini G, Huqi A, Morrone D, Patel MR, Weintraub WS (2012) Obstructive coronary atherosclerosis and ischemic heart disease: an elusive link! J Am Coll Cardiol 60:951-956. https://doi.org/10.1016/j.jacc.2012.02.082

55. Matsusaka T, Hasebe N, Jin YT, Kawabe J, Kikuchi K (2002) Magnesium reduces myocardial infarct size via enhancement of adenosine mechanism in rabbits. Cardiovasc Res 54:568-575. https://doi.org/10.1016/s0008-6363(02)00253-5

56. Merkus D, Haitsma DB, Fung TY, Assen YJ, Verdouw PD, Duncker DJ (2003) Coronary blood flow regulation in exercising swine involves parallel rather than redundant vasodilator pathways. Am J Physiol Heart Circ Physiol 285:H424-433. https:// doi.org/10.1152/ajpheart.00916.2002

57. Michel JB, Thaunat O, Houard X, Meilhac O, Caligiuri G, Nicoletti A (2007) Topological determinants and consequences of adventitial responses to arterial wall injury. Arterioscler Thromb Vasc Biol 27:1259-1268. https://doi.org/10.1161/ATVBAHA. 106.137851

58. Mishra RC, Wulff H, Cole WC, Braun AP (2014) A pharmacologic activator of endothelial $\mathrm{KCa}$ channels enhances coronary flow in the hearts of type 2 diabetic rats. J Mol Cell Cardiol 72:364-373. https://doi.org/10.1016/j.yjmcc.2014.04.013

59. Morrison RR, Talukder MA, Ledent C, Mustafa SJ (2002) Cardiac effects of adenosine in $\mathrm{A}(2 \mathrm{~A})$ receptor knockout hearts: uncovering A(2B) receptors. Am J Physiol Heart Circ Physiol 282:H437-444. https://doi.org/10.1152/ajpheart.00723.2001

60. Mustafa SJ, Morrison RR, Teng B, Pelleg A (2009) Adenosine receptors and the heart: role in regulation of coronary blood flow and cardiac electrophysiology. Handb Exp Pharmacol 4:161188. https://doi.org/10.1007/978-3-540-89615-9_6

61. Navarese EP, Buffon A, Andreotti F, Gurbel PA, Kozinski M, Kubica A, Musumeci G, Cremonesi A, Tavazzi L, Kubica J, Castriota F (2012) Adenosine improves post-procedural coronary flow but not clinical outcomes in patients with acute coronary syndrome: a meta-analysis of randomized trials. Atherosclerosis 222:1-7. https://doi.org/10.1016/j.atherosclerosis.2011.11.001

62. Neglia D, Fommei E, Varela-Carver A, Mancini M, Ghione S, Lombardi M, Pisani P, Parker H, D’Amati G, Donato L, Camici PG (2011) Perindopril and indapamide reverse coronary microvascular remodelling and improve flow in arterial hypertension. J Hypertens 29:364-372. https://doi.org/10.1097/HJH.0b013e3283 $40 \mathrm{a} 08 \mathrm{e}$

63. Nguyen DK, Montesinos MC, Williams AJ, Kelly M, Cronstein BN (2003) Th1 cytokines regulate adenosine receptors and their downstream signaling elements in human microvascular endothelial cells. J Immunol 171:3991-3998. https://doi.org/10.4049/ jimmunol.171.8.3991

64. Nishijima Y, Cao S, Chabowski DS, Korishettar A, Ge A, Zheng X, Sparapani R, Gutterman DD, Zhang DX (2017) Contribution of KV1.5 channel to hydrogen peroxide-induced human arteriolar dilation and its modulation by coronary artery disease. Circ Res 120:658-669. https://doi.org/10.1161/CIRCRESAHA.116. 309491

65. Obata T, Sato T, Yamanaka Y, Arita M (1998) NO and cGMP facilitate adenosine production in rat hearts via activation of 
ecto-5'-nucleotidase. Pflugers Arch 436:984-990. https://doi. org/10.1007/s004240050733

66. Ohman J, Kudira R, Albinsson S, Olde B, Erlinge D (2012) Ticagrelor induces adenosine triphosphate release from human red blood cells. Biochem Biophys Res Commun 418:754-758. https://doi.org/10.1016/j.bbrc.2012.01.093

67. Olanrewaju HA, Qin W, Feoktistov I, Scemama JL, Mustafa SJ (2000) Adenosine $\mathrm{A}(2 \mathrm{~A})$ and $\mathrm{A}(2 \mathrm{~B})$ receptors in cultured human and porcine coronary artery endothelial cells. Am J Physiol Heart Circ Physiol 279:H650-656. https://doi.org/10.1152/ajpheart. 2000.279.2.H650

68. Olivecrona GK, Gotberg M, Harnek J, Wang L, Jacobson KA, Erlinge D (2004) Coronary artery reperfusion: The ADP receptor $\mathrm{P} 2 \mathrm{Y}(1)$ mediates early reactive hyperemia in vivo in pigs. Purinergic Signal 1:59-65. https://doi.org/10.1007/ s11302-004-4742-7

69. Olsson RA, Khouri EM, Bedynek JL Jr, McLean J (1979) Coronary vasoactivity of adenosine in the conscious dog. Circ Res 45:468-478. https://doi.org/10.1161/01.res.45.4.468

70. Paulus WJ, Tschope C (2013) A novel paradigm for heart failure with preserved ejection fraction: comorbidities drive myocardial dysfunction and remodeling through coronary microvascular endothelial inflammation. J Am Coll Cardiol 62:263-271. https://doi.org/10.1016/j.jacc.2013.02.092

71. Pekka Raatikainen MJ, Peuhkurinen KJ, Hassinen IE (1991) Cellular source and role of adenosine in isoproterenol-induced coronary vasodilatation. J Mol Cell Cardiol 23:1137-1148. https://doi.org/10.1016/0022-2828(91)90203-X

72. Pepine CJ, Anderson RD, Sharaf BL, Reis SE, Smith KM, Handberg EM, Johnson BD, Sopko G, Bairey Merz CN (2010) Coronary microvascular reactivity to adenosine predicts adverse outcome in women evaluated for suspected ischemia results from the National Heart, Lung and Blood Institute WISE (Women's Ischemia Syndrome Evaluation) study. J Am Coll Cardiol 55:2825-2832. https://doi.org/10.1016/j.jacc. 2010.01.054

73. Reiss AB, Grossfeld D, Kasselman LJ, Renna HA, Vernice NA, Drewes W, Konig J, Carsons SE, DeLeon J (2019) Adenosine and the cardiovascular system. Am J Cardiovasc Drugs 19:449464. https://doi.org/10.1007/s40256-019-00345-5

74. Rodriguez-Porcel M, Zhu X, Chade A, Amores-Arriaga B, Caplice N, Ritman E, Lerman A, Lerman LJ (2006) Functional and structural remodeling of the myocardial microvasculature in early experimental hypertension. AJOPH Physiol 290:H978-984. https://doi.org/10.1152/ajpheart.00538.2005

75. Rogers PA, Chilian WM, Bratz IN, Bryan RM Jr, Dick GM (2007) H2O2 activates redox- and 4-aminopyridine-sensitive $\mathrm{Kv}$ channels in coronary vascular smooth muscle. Am J Physiol Heart Circ Physiol 292:H1404-1411. https://doi.org/10.1152/ ajpheart.00696.2006

76. Rubio R, Ceballos G (2003) Sole activation of three luminal adenosine receptor subtypes in different parts of coronary vasculature. Am J Physiol Heart Circ Physiol 284:H204-214. https:// doi.org/10.1152/ajpheart.00068.2002

77. Ryzhov S, Solenkova NV, Goldstein AE, Lamparter M, Fleenor T, Young PP, Greelish JP, Byrne JG, Vaughan DE, Biaggioni I, Hatzopoulos AK, Feoktistov I (2008) Adenosine receptor-mediated adhesion of endothelial progenitors to cardiac microvascular endothelial cells. Circ Res 102:356-363. https://doi.org/10.1161/ CIRCRESAHA.107.158147

78. Sanjani MS, Teng B, Krahn T, Tilley S, Ledent C, Mustafa SJ (2011) Contributions of A2A and A2B adenosine receptors in coronary flow responses in relation to the KATP channel using A2B and A2A/2B double-knockout mice. Am J Physiol Heart Circ Physiol 301:H2322-2333. https://doi.org/10.1152/ajpheart. 00052.2011
79. Sato A, Terata K, Miura H, Toyama K, Loberiza FR Jr, Hatoum OA, Saito T, Sakuma I, Gutterman DD (2005) Mechanism of vasodilation to adenosine in coronary arterioles from patients with heart disease. Am J Physiol Heart Circ Physiol 288:H16331640. https://doi.org/10.1152/ajpheart.00575.2004

80. Schindler TH, Dilsizian V (2020) Coronary microvascular dysfunction: clinical considerations and noninvasive diagnosis. JACC Cardiovasc Imaging 13:140-155. https://doi.org/10.1016/j. jcmg.2018.11.036

81. Schrader J, Deussen A, Smolenski RT (1990) Adenosine is a sensitive oxygen sensor in the heart. Experientia 46:1172-1175. https://doi.org/10.1007/BF01936930

82. Schrader J, Schutz W, Bardenheuer H (1981) Role of S-adenosylhomocysteine hydrolase in adenosine metabolism in mammalian heart. Biochem J 196:65-70. https://doi.org/10.1042/bj1960065

83. Schulz R, Rose J, Post H, Heusch G (1995) Involvement of endogenous adenosine in ischaemic preconditioning in swine. Pflugers Arch 430:273-282. https://doi.org/10.1007/BF003 74659

84. Sellke FW, Armstrong ML, Harrison DG (1990) Endotheliumdependent vascular relaxation is abnormal in the coronary microcirculation of atherosclerotic primates. Circulation 81:15861593. https://doi.org/10.1161/01.cir.81.5.1586

85. Severino P, D'Amato A, Pucci M, Infusino F, Adamo F, Birtolo LI, Netti L, Montefusco G, Chimenti C, Lavalle C, Maestrini V, Mancone M, Chilian WM, Fedele F (2020) Ischemic heart disease pathophysiology paradigms overview: from plaque activation to microvascular dysfunction. Int J Mol Sci. https://doi. org/10.3390/ijms21218118

86. Sharifi-Sanjani M, Zhou X, Asano S, Tilley S, Ledent C, Teng B, Dick GM, Mustafa SJ (2013) Interactions between A(2A) adenosine receptors, hydrogen peroxide, and KATP channels in coronary reactive hyperemia. Am J Physiol Heart Circ Physiol 304:H1294-1301. https://doi.org/10.1152/ajpheart.00637.2012

87. Skyschally A, Schulz R, Gres P, Konietzka I, Martin C, Haude M, Erbel R, Heusch G (2004) Coronary microembolization does not induce acute preconditioning against infarction in pigs-the role of adenosine. Cardiovasc Res 63:313-322. https://doi.org/ 10.1016/j.cardiores.2004.04.003

88. Sorop O, Olver TD, van de Wouw J, Heinonen I, van Duin RW, Duncker DJ, Merkus D (2017) The microcirculation: a key player in obesity-associated cardiovascular disease. Cardiovasc Res 113:1035-1045. https://doi.org/10.1093/cvr/cvx093

89. Sorop O, van de Wouw J, Chandler S, Ohanyan V, Tune JD, Chilian WM, Merkus D, Bender SB, Duncker DJ (2020) Experimental animal models of coronary microvascular dysfunction. Cardiovasc Res 116:756-770. https://doi.org/10.1093/cvr/cvaa0 02

90. Suarez J, Chagoya de Sanchez V (1997) Inhibition of S-adenosyl-L-homocysteine hydrolase by adrenaline in isolated guineapig papillary muscles. Int J Biochem Cell Biol 29:1279-1284. https://doi.org/10.1016/s1357-2725(97)00069-1

91. Sun C, Jiao T, Merkus D, Duncker DJ, Mustafa SJ, Zhou Z (2019) Activation of adenosine A2A but not A2B receptors is involved in uridine adenosine tetraphosphate-induced porcine coronary smooth muscle relaxation. J Pharmacol Sci 141:64-69. https://doi.org/10.1016/j.jphs.2019.09.006

92. Talukder MA, Morrison RR, Jacobson MA, Jacobson KA, Ledent C, Mustafa SJ (2002) Targeted deletion of adenosine A(3) receptors augments adenosine-induced coronary flow in isolated mouse heart. Am J Physiol Heart Circ Physiol 282:H2183-2189. https://doi.org/10.1152/ajpheart.00964.2001

93. Talukder MA, Morrison RR, Ledent C, Mustafa SJ (2003) Endogenous adenosine increases coronary flow by activation of both $\mathrm{A} 2 \mathrm{~A}$ and $\mathrm{A} 2 \mathrm{~B}$ receptors in mice. J Cardiovasc 
Pharmacol 41:562-570. https://doi.org/10.1097/00005344-20030 4000-00008

94. Taqueti VR, Di Carli MF (2018) Coronary microvascular disease pathogenic mechanisms and therapeutic options: JACC state-ofthe-art review. J Am Coll Cardiol 72:2625-2641. https://doi.org/ 10.1016/j.jacc.2018.09.042

95. Tawfik HE, Teng B, Morrison RR, Schnermann J, Mustafa SJ (2006) Role of A1 adenosine receptor in the regulation of coronary flow. Am J Physiol Heart Circ Physiol 291:H467-472. https://doi.org/10.1152/ajpheart.01319.2005

96. Teng B, Ledent C, Mustafa SJ (2008) Up-regulation of A 2B adenosine receptor in A $2 \mathrm{~A}$ adenosine receptor knockout mouse coronary artery. J Mol Cell Cardiol 44:905-914. https://doi.org/ 10.1016/j.yjmcc.2008.03.003

97. Teng B, Mustafa SJ (2011) A(2A) adenosine receptor-mediated increase in coronary flow in hyperlipidemic APOE-knockout mice. J Exp Pharmacol 21:59-68. https://doi.org/10.2147/JEP. S18945

98. Teng B, Qin W, Ansari HR, Mustafa SJ (2005) Involvement of p38-mitogen-activated protein kinase in adenosine receptormediated relaxation of coronary artery. Am J Physiol Heart Circ Physiol 288:H2574-2580. https://doi.org/10.1152/ajpheart. 00912.2004

99. Teng B, Tilley SL, Ledent C, Mustafa SJ (2016) In vivo assessment of coronary flow and cardiac function after bolus adenosine injection in adenosine receptor knockout mice. Physiol Rep. https://doi.org/10.14814/phy2.12818

100. Tune JD, Richmond KN, Gorman MW, Olsson RA, Feigl EO (2000) Adenosine is not responsible for local metabolic control of coronary blood flow in dogs during exercise. Am J Physiol Heart Circ Physiol 278:H74-84. https://doi.org/10.1152/ajpheart. 2000.278.1.H74

101. van Giezen JJ, Sidaway J, Glaves P, Kirk I, Bjorkman JA (2012) Ticagrelor inhibits adenosine uptake in vitro and enhances adenosine-mediated hyperemia responses in a canine model. $\mathbf{J}$ Cardiovasc Pharmacol Ther 17:164-172. https://doi.org/10.1177/ 1074248411410883

102. van Haare J, Kooi ME, Vink H, Post MJ, van Teeffelen JW, Slenter J, Munts C, Cobelens H, Strijkers GJ, Koehn D, van Bilsen M (2015) Early impairment of coronary microvascular perfusion capacity in rats on a high fat diet. Cardiovasc Diabetol 14:150. https://doi.org/10.1186/s12933-015-0312-2

103. Vanhaecke J, Flameng W, Borgers M, Jang IK, Van de Werf F, De Geest H (1990) Evidence for decreased coronary flow reserve in viable postischemic myocardium. Circ Res 67:1201-1210. https://doi.org/10.1161/01.res.67.5.1201

104. Visser F, Vickers MF, Ng AM, Baldwin SA, Young JD, Cass CE (2002) Mutation of residue 33 of human equilibrative nucleoside transporters 1 and 2 alters sensitivity to inhibition of transport by dilazep and dipyridamole. J Biol Chem 277:395-401. https:// doi.org/10.1074/jbc.M105324200

105. Volz S, Svedlund S, Andersson B, Li-Ming G, Rundqvist B (2017) Coronary flow reserve in patients with resistant hypertension. Clin Res Cardiol 106:151-157. https://doi.org/10.1007/ s00392-016-1043-4

106. von Beckerath N, Cyrys S, Dischner A, Daut J (1991) Hypoxic vasodilatation in isolated, perfused guinea-pig heart: an analysis of the underlying mechanisms. J Physiol 442:297-319. https:// doi.org/10.1113/jphysiol.1991.sp018794

107. Wallentin L, Becker RC, Budaj A, Cannon CP, Emanuelsson H, Held C, Horrow J, Husted S, James S, Katus H, Mahaffey KW, Scirica BM, Skene A, Steg PG, Storey RF, Harrington RA, Investigators P, Freij A, Thorsen M (2009) Ticagrelor versus clopidogrel in patients with acute coronary syndromes. N Engl $\mathrm{J}$ Med 361:1045-1057. https://doi.org/10.1056/NEJMoa0904327
108. Wang J, Whitt SP, Rubin LJ, Huxley VH (2005) Differential coronary microvascular exchange responses to adenosine: roles of receptor and microvessel subtypes. Microcirculation 12:313-326. https://doi.org/10.1080/10739680590934736

109. Watt AH, Penny WJ, Singh H, Routledge PA, Henderson AH (1987) Adenosine causes transient dilatation of coronary arteries in man. Br J Clin Pharmacol 24:665-668. https://doi.org/10. 1111/j.1365-2125.1987.tb03227.x

110. Wernly B, Erlinge D, Pernow J, Zhou Z (2020) Ticagrelor: a cardiometabolic drug targeting erythrocyte-mediated purinergic signaling? Am J Physiol Heart Circ Physiol. https://doi.org/10. 1152/ajpheart.00570.2020

111. Wernly B, Zhou Z (2020) More purinergic receptors deserve attention as therapeutic targets for the treatment of cardiovascular disease. Am J Physiol Heart Circ Physiol 319:H723-H729. https://doi.org/10.1152/ajpheart.00417.2020

112. Wittfeldt A, Emanuelsson H, Brandrup-Wognsen G, van Giezen JJ, Jonasson J, Nylander S, Gan LM (2013) Ticagrelor enhances adenosine-induced coronary vasodilatory responses in humans. J Am Coll Cardiol 61:723-727. https://doi.org/10.1016/j.jacc. 2012.11.032

113. Woods KL, Fletcher S (1994) Long-term outcome after intravenous magnesium sulphate in suspected acute myocardial infarction: the second leicester intravenous magnesium intervention trial (LIMIT-2). Lancet 343:816-819. https://doi.org/10.1016/ s0140-6736(94)92024-9

114. Xu J, Nagata K, Obata K, Ichihara S, Izawa H, Noda A, Nagasaka T, Iwase M, Naoe T, Murohara T, Yokota MJH (2005) Nicorandil promotes myocardial capillary and arteriolar growth in the failing heart of Dahl salt-sensitive hypertensive rats. Hypertension 46:719-724. https://doi.org/10.1161/01.Hyp.0000185189.46698. 15

115. Yada T, Richmond KN, Van Bibber R, Kroll K, Feigl EO (1999) Role of adenosine in local metabolic coronary vasodilation. Am J Physiol 276:H1425-1433. https://doi.org/10.1152/ajpheart.1999. 276.5.H1425

116. Yada T, Shimokawa H, Hiramatsu O, Kajita T, Shigeto F, Goto M, Ogasawara Y, Kajiya F (2003) Hydrogen peroxide, an endogenous endothelium-derived hyperpolarizing factor, plays an important role in coronary autoregulation in vivo. Circulation 107:1040-1045. https://doi.org/10.1161/01.cir.0000050145. 25589.65

117. Zatta AJ, Headrick JP (2005) Mediators of coronary reactive hyperaemia in isolated mouse heart. Br J Pharmacol 144:576587. https://doi.org/10.1038/sj.bjp.0706099

118. Zhang DX, Borbouse L, Gebremedhin D, Mendoza SA, Zinkevich NS, Li R, Gutterman DD (2012) H2O2-induced dilation in human coronary arterioles: role of protein kinase $\mathrm{G}$ dimerization and large-conductance $\mathrm{Ca} 2+$-activated $\mathrm{K}+$ channel activation. Circ Res 110:471-480. https://doi.org/10.1161/CIRCRESAHA. 111.258871

119. Zhou R, Dang X, Sprague RS, Mustafa SJ, Zhou Z (2020) Alteration of purinergic signaling in diabetes: focus on vascular function. J Mol Cell Cardiol 140:1-9. https://doi.org/10.1016/j.yjmcc. 2020.02.004

120. Zhou X, Teng B, Mustafa SJ (2015) Sex difference in coronary endothelial dysfunction in apolipoprotein $\mathrm{E}$ knockout mouse: role of NO and A2A adenosine receptor. Microcirculation 22:518527. https://doi.org/10.1111/micc. 12222

121. Zhou X, Teng B, Tilley S, Ledent C, Mustafa SJ (2014) Metabolic hyperemia requires ATP-sensitive $\mathrm{K}+$ channels and $\mathrm{H} 2 \mathrm{O} 2$ but not adenosine in isolated mouse hearts. Am J Physiol Heart Circ Physiol 307:H1046-1055. https://doi.org/10.1152/ajpheart. 00421.2014

122. Zhou X, Teng B, Tilley S, Mustafa SJ (2013) A1 adenosine receptor negatively modulates coronary reactive hyperemia via 
counteracting A2A-mediated $\mathrm{H} 2 \mathrm{O} 2$ production and KATP opening in isolated mouse hearts. Am J Physiol Heart Circ Physiol 305:H1668-1679. https://doi.org/10.1152/ajpheart.00495.2013

123. Zhou Z, de Wijs-Meijler D, Lankhuizen I, Jankowski J, Jankowski V, Jan Danser AH, Duncker DJ, Merkus D (2013) Blunted coronary vasodilator response to uridine adenosine tetraphosphate in post-infarct remodeled myocardium is due to reduced $\mathrm{P} 1$ receptor activation. Pharmacol Res 77:22-29. https://doi.org/10.1016/j. phrs.2013.08.007

124. Zhou Z, Matsumoto T, Jankowski V, Pernow J, Mustafa SJ, Duncker DJ, Merkus D (2019) Uridine adenosine tetraphosphate and purinergic signaling in cardiovascular system: an update. Pharmacol Res 141:32-45. https://doi.org/10.1016/j.phrs.2018. 12.009

125. Zhou Z, Merkus D, Cheng C, Duckers HJ, Jan Danser AH, Duncker DJ (2013) Uridine adenosine tetraphosphate is a novel vasodilator in the coronary microcirculation which acts through purinergic P1 but not P2 receptors. Pharmacol Res 67:10-17. https://doi.org/10.1016/j.phrs.2012.09.011

126. Zhou Z, Rajamani U, Labazi H, Tilley SL, Ledent C, Teng B, Mustafa SJ (2015) Involvement of NADPH oxidase in A2A adenosine receptor-mediated increase in coronary flow in isolated mouse hearts. Purinergic Signal 11:263-273. https://doi.org/10. 1007/s11302-015-9451-x

127. Ziegler T, Abdel Rahman F, Jurisch V, Kupatt C (2019) Atherosclerosis and the capillary network; pathophysiology and potential therapeutic strategies. Cells. https://doi.org/10.3390/ cells 9010050

128. Zucchi R, Limbruno U, Poddighe R, Mariani M, Ronca G (1989) The adenosine hypothesis revisited: relationship between purine release and coronary flow in isolated rat heart. Cardiovasc Res 23:125-131. https://doi.org/10.1093/cvr/23.2.125 